\title{
Belgium: 2007 Article IV Consultation-Staff Report; Staff Supplement; and Public Information Notice on the Executive Board Discussion
}

Under Article IV of the IMF's Articles of Agreement, the IMF holds bilateral discussions with members, usually every year. In the context of the 2007 Article IV consultation with Belgium, the following documents have been released and are included in this package:

- $\quad$ The staff report for the 2007 Article IV consultation, prepared by a staff team of the IMF, following discussions that ended on January 28, 2008, with the officials of Belgium on economic developments and policies. Based on information available at the time of these discussions, the staff report was completed on February 28, 2008. The views expressed in the staff report are those of the staff team and do not necessarily reflect the views of the Executive Board of the IMF.

- $\quad$ A staff supplement of March 19, 2008 updating information on recent developments.

- $\quad$ A Public Information Notice (PIN) summarizing the views of the Executive Board as expressed during its March 21, 2008 discussion of the staff report that concluded the Article IV consultation.

The policy of publication of staff reports and other documents allows for the deletion of market-sensitive information.

Copies of this report are available to the public from

International Monetary Fund $\bullet$ Publication Services

$70019^{\text {th }}$ Street, N.W. $\bullet$ Washington, D.C. 20431

Telephone: (202) 623-7430 • Telefax: (202) 623-7201

E-mail: publications@imf.org・Internet: http://www.imf.org

Price: $\$ 18.00$ a copy

\section{International Monetary Fund \\ Washington, D.C.}





\title{
INTERNATIONAL MONETARY FUND
}

\author{
BELGIUM
}

\section{Staff Report for the 2007 Article IV Consultation}

\author{
Prepared by Staff Representatives for the 2007 Consultation with Belgium \\ Approved by Alessandro Leipold and Michael Hadjimichael
}

February 28, 2008

\section{EXECUTIVE SUMMARY}

Headwinds from a more testing international environment and domestic political tensions are challenging Belgium's enviable economic performance. Economic growth is expected to decelerate significantly - in the staff's view to 1.6 percent in 2008, though the authorities remain somewhat more sanguine. The recent spike in energy and food prices will likely push average inflation to 2.9 percent in 2008. Partial indexation will temper its impact on real incomes, but poses risks to competitiveness. With political tensions following the June 2007 elections, federal policy making has been at a standstill since April 2007, delaying much needed fiscal consolidation and structural reforms. Meanwhile, the window to tackle the implications of population aging - through fiscal pre-funding and higher growth - is closing rapidly.

The impact of financial turmoil on the financial system appears contained but, together with heightened cross-border integration, will continue to require the dedicated attention of supervisors. While not ruling out downside surprises, especially in the event of a severe and prolonged economic downturn, supervisors indicated that financial institutions remained sound. More transparent disclosure of exposures and valuation assumptions and their implications for banks' earnings and capital would dampen market volatility. While already high-quality prudential supervision is being further enhanced, the relentless rise in the crossborder dimension of the financial system requires stronger coordination with host country authorities.

Though the policy agenda to address aging and fiscal federalism imbalances is well known, timely delivery is not certain. On the positive side, fiscal consolidation is set to resume in 2008, without recourse to significant one-off measures. But plans fall short of staff advice and the urgent reform of fiscal federalism arrangements will need to be executed without fiscal costs. Greater accountability, more transparency, and stronger coordination among federal and sub-federal entities are key to achieving the required medium-term buildup of fiscal surpluses. Structural reforms will need to resume without delay to boost employment rates and productivity. 
Executive Summary 1

I. Introduction 4

II. Outlook: Supporting Growth, Managing Inflation, and Preserving Competitiveness ..........5

A. How Significant a Slowdown Lies Ahead? ..........................................................

B. How is Inflation Affecting the Economy? .......................................................

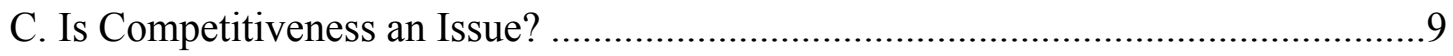

III. Financial Sector: Addressing Turbulence and Enhancing Stability ..............................11

A. How is the Financial System Coping with Financial Turbulence?.......................11

B. Will Financial Strains Impact the Real Economy? ............................................13

C. How Can Financial Stability be Further Enhanced? ...........................................15

IV. Fiscal Policy: Resuming Consolidation and Improving Institutions .............................16

A. Why has Fiscal Consolidation Become an Urgent Priority? .................................16

B. Why is There a Need to Revise Fiscal Federalism Arrangements? .......................20

V. Structural Reforms: Raising Employment and Productivity ......................................2 21

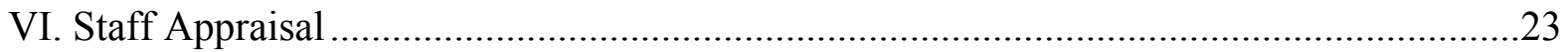

Text Box

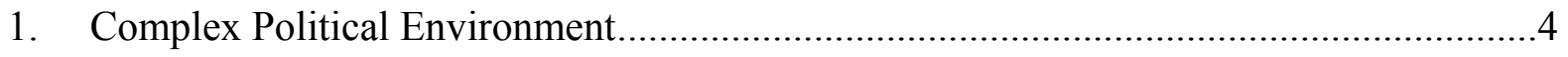

Text Tables

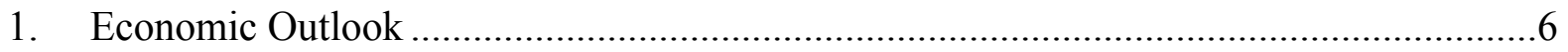

2. Inflation Impact on Lowest Income Group...........................................................

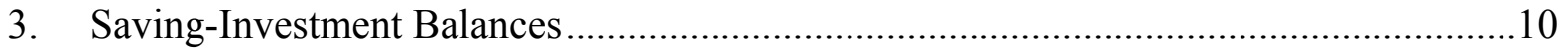

4. Unit Labor Costs in the Private Sector, 2003-08 ....................................................11

5. General Government Fiscal Indicators, 2003-2009 .................................................17

6. Fiscal Accounts by Level of Government, 2002-2007 ...........................................19

Tables

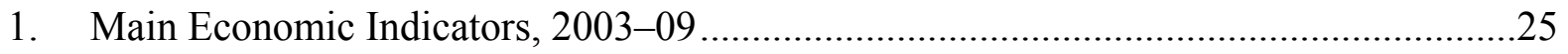

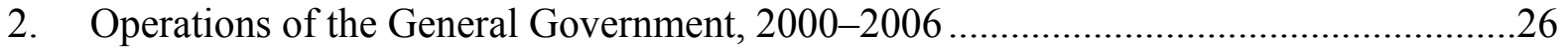

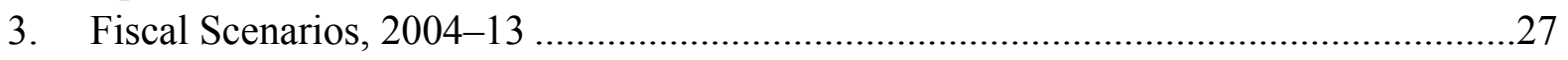

4. Financial Soundness Indicators of the Non-Banking Sectors, 2001-07 .......................28

5. Financial Soundness Indicators of the Banking Sector, 2002-07 ...............................29

6. Indicators of External and Financial Vulnerability, 2001-07 .....................................30 
Figures

1. Political Tensions and Sovereign Spreads ...........................................................

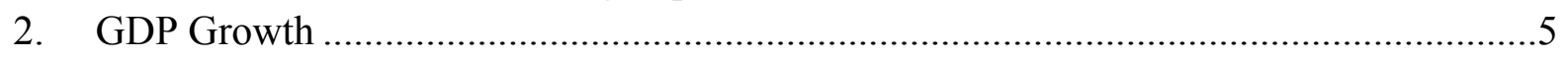

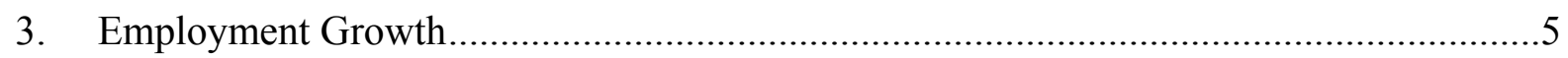

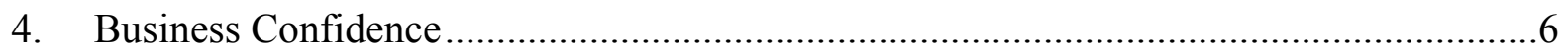

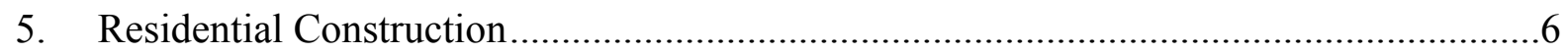

6. Real GDP Growth: Risks to the Forecast .............................................................. 7

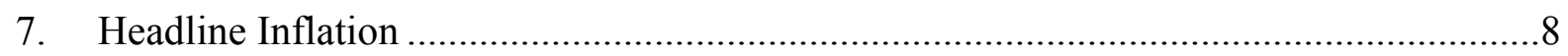

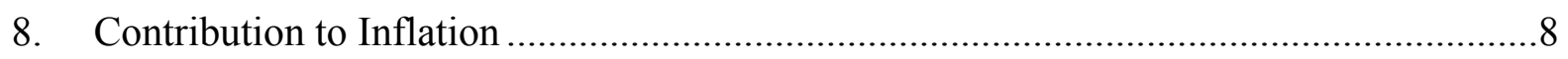

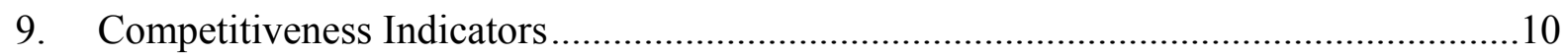

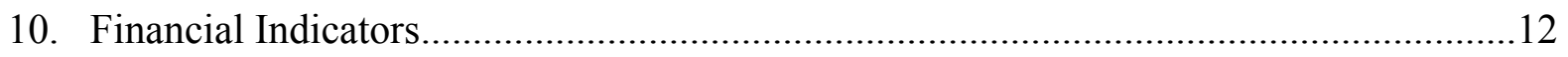

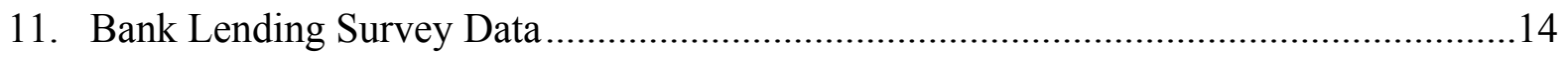

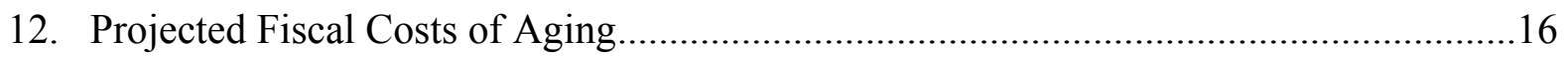

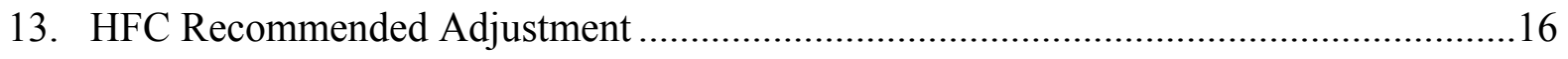

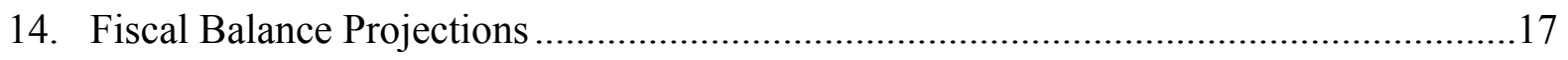

15. Vertical Imbalance - Aging-Related Spending ....................................................20

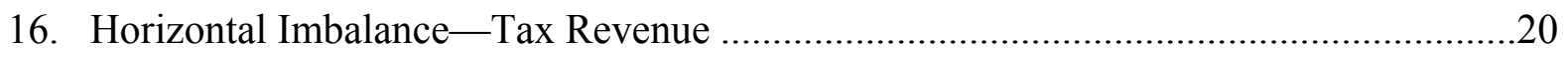

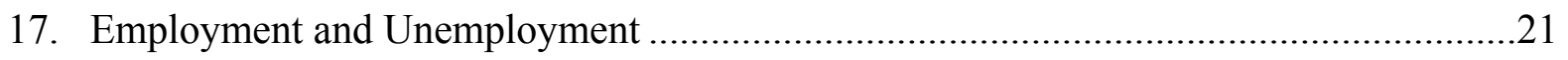

Appendix

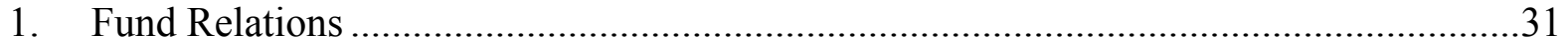

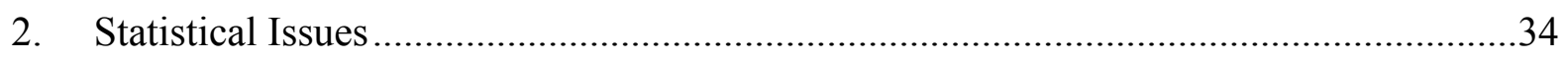




\section{INTRODUCTION}

\section{While economic performance has remained good, difficulties in building consensus for institutional reform have caused an ill-affordable hiatus in economic} policy making. Economic growth was robust in 2007, bringing down unemployment to the lowest level since 2002. As elsewhere in the euro area, growth is expected to slow significantly owing to a weakening of the international environment and financial turbulence, though the domestic financial system appears to be resilient. The recent spike in energy and food prices is of concern, as partial indexation may pose risks to competitiveness. More worrisome is the interruption in policy-making at the federal level, broadly since April 2007, reflecting a complex political environment (Box 1). The coordinated early and decisive policy response to tackle long-term challenges that Executive Directors called for in last year's consultation has thus remained absent.

\section{Box 1. Complex Political Environment}

In the June 2007 federal elections, voters rejected the outgoing left-right coalition and put the center Christian Democrats in a commanding position to form a new coalition, but disagreements on reforms of fiscal federalism arrangements led to a 6-month political impasse. In the absence of a federal government, policy making continued only at the regional, community, and local levels but without the usual coordination mechanisms.

To deal with urgent policy matters, especially the 2008 budget, an interim federal government was formed on December 21, 2007, under outgoing Prime Minister Verhofstadt. A regular federal government is expected to be put in place by March 23, 2008, consisting of the same coalition partners but headed by a new Prime Minister. However, serious tensions remain within the coalition, especially surrounding constitutional reforms, and the policy agenda is already being influenced by

Figure 1. Political Tensions and Sovereign Spreads the perspective of the regional elections of 2009.

The impact of the political uncertainty can be seen in movements in sovereign spreads (Figure 1), with spikes in political tensions ${ }^{1}$ leading to their widening. Indeed, fiscal policy has so far been the main victim of the political turmoil: the general government is likely to record a deficit of 0.1 percent of GDP in 2007 instead of the targeted surplus of 0.3 percent of GDP required under the previously agreed strategy to deal with aging.

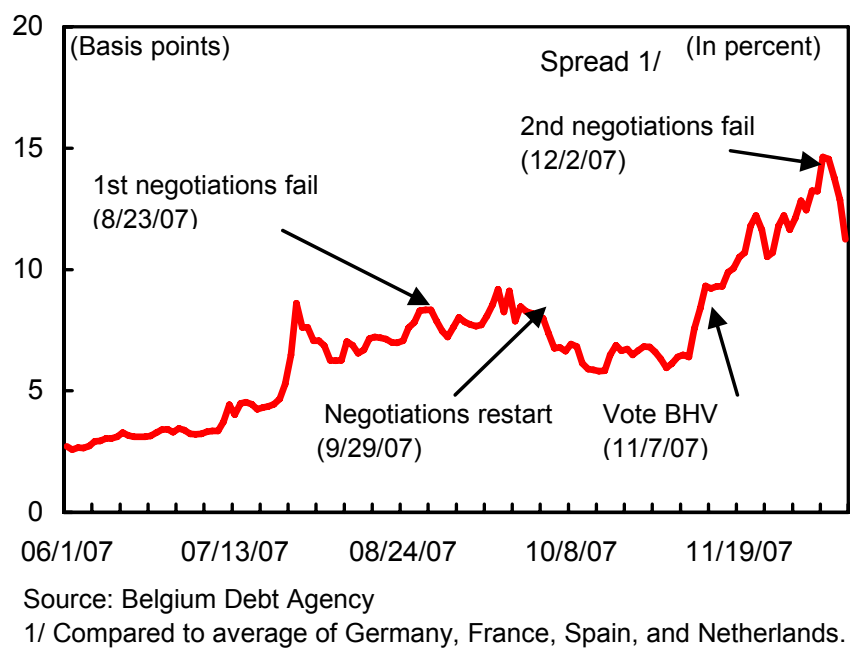

${ }^{1}$ Political tensions peaked when negotiations to form a government failed twice and when a dispute over an electoral district (BHV) evoked the specter of a partition of the country. 


\section{Outlook: Supporting Growth, Managing Inflation, And Preserving COMPETITIVENESS}

\section{A. How Significant a Slowdown Lies Ahead?}

2. A mostly favorable global environment and strong domestic demand delivered robust economic growth in 2007 (Figure 2). The strong performance of Germany and emerging markets as well as easy financing conditions created a supportive external environment during most of the year. Domestically, household and business confidence indicators rose significantly, inflation was subdued, and job creation increased significantly. All in all, GDP rose by 2.7 percent in 2007 .

\section{Robust economic activity absorbed a} growing labor force and allowed the unemployment rate to decline continuously (Figure 3 ). In addition to cyclical factors, employment growth also benefited from a sharp increase in the selfemployed, associated with labor immigration following EU enlargement, and the government-subsidized voucher program for domestic services which led to the creation of low-skill jobs in the services sector. As a result, 55,000 jobs were added during the first 9 months of 2007, raising households' net disposable income which, in turn, spurred strong consumption growth. Meanwhile, labor shortages have started to appear in some regions and sectors.
Figure 2. GDP Growth

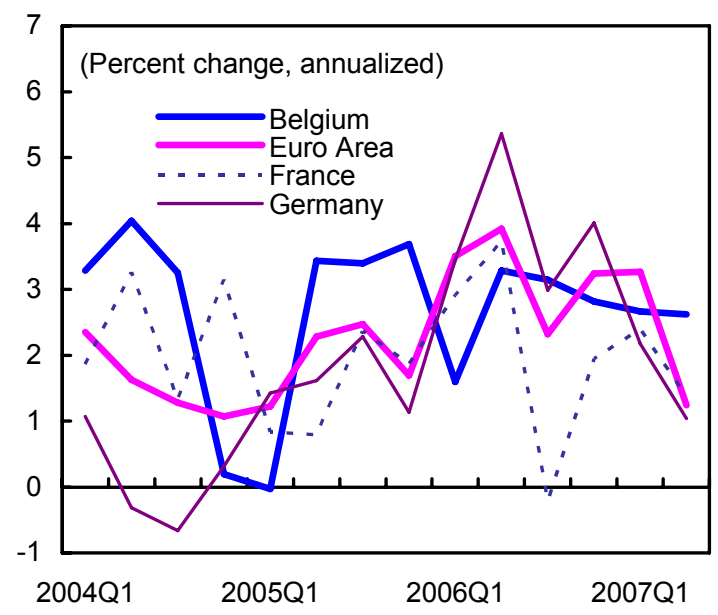

Source: WEO

Figure 3. Employment Growth

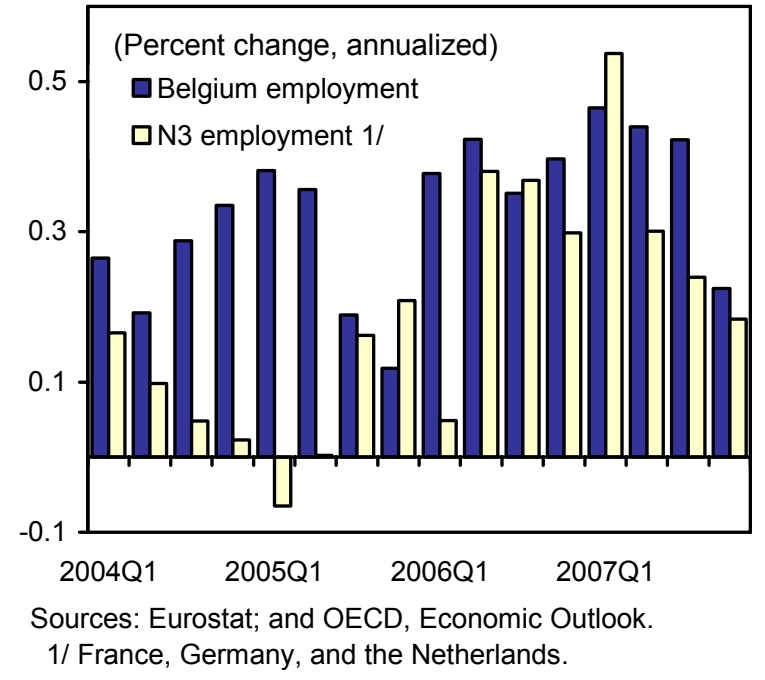

4. The authorities and staff agreed that growth would decline significantly, but differed on the degree of the slowdown. The authorities' macroeconomic framework underlying the budget is based on GDP growth of 1.9 percent in 2008, which they felt was only slightly on the optimistic side. The staff expects economic growth to fall to 1.6 percent (Text Table 1). There was agreement that the slowdown would affect all demand components. Business investment is expected to decelerate due to greater uncertainty and to a lesser extent because of less favorable financing conditions (Figure 4). Residential 
construction will ease from historic highs in line with developments in house prices and mortgage markets (Figure 5). ${ }^{1}$ Consumption will grow at a lower pace mostly due to sluggish real disposable income growth as inflation rises and the pace of job creation diminishes. However, with consumer credit less developed than in Anglo-Saxon countries, the drag from less favorable financing conditions will be smaller. Finally, the global slowdown and euro appreciation will dampen export growth.

Text Table 1. Economic Outlook

(Annual growth rates from previous period, unless otherwise indicated)

\begin{tabular}{|c|c|c|c|c|c|c|c|c|c|c|c|c|}
\hline & \multirow[b]{3}{*}{2005} & \multirow[b]{3}{*}{2006} & \multirow{3}{*}{$\begin{array}{l}\text { Est. } \\
2007\end{array}$} & \multirow{3}{*}{$\begin{array}{l}\text { Proj. } \\
2008\end{array}$} & \multirow{2}{*}{\multicolumn{4}{|c|}{ Est. }} & \multicolumn{4}{|c|}{ Projections } \\
\hline & & & & & & & & & \multicolumn{4}{|c|}{2008} \\
\hline & & & & & Q1 & Q2 & Q3 & Q4 & Q1 & Q2 & Q3 & Q4 \\
\hline Real GDP (constant prices) & 2.0 & 2.9 & 2.7 & 1.6 & 3.0 & 2.8 & 2.6 & 2.4 & 2.0 & 1.6 & 1.4 & 1.4 \\
\hline Private consumption expenditure & 1.4 & 2.1 & 2.5 & 1.5 & 1.9 & 2.4 & 2.8 & 2.9 & 2.4 & 1.7 & 1.0 & 1.1 \\
\hline Gross fixed capital formation & 6.7 & 4.2 & 4.9 & 1.4 & 4.8 & 4.7 & 4.2 & 6.1 & 2.6 & 1.2 & 1.0 & 0.7 \\
\hline Unemployment rate & 8.4 & 8.2 & 7.5 & 7.4 & $\ldots$ & $\ldots$ & $\ldots$ & $\ldots$ & $\ldots$ & $\ldots$ & $\ldots$ & $\ldots$ \\
\hline Consumer price index & 2.5 & 2.3 & 1.8 & 2.9 & 1.8 & 1.5 & 1.3 & 2.6 & 3.3 & 3.1 & 2.8 & 2.6 \\
\hline General government balance (in percent of GDP) & -2.3 & 0.4 & -0.1 & -0.5 & $\ldots$ & $\ldots$ & $\ldots$ & $\ldots$ & $\ldots$ & $\ldots$ & $\ldots$ & $\ldots$ \\
\hline Current account balance (in percent of GDP) & 2.6 & 2.7 & 3.3 & 3.0 & $\ldots$ & $\ldots$ & $\ldots$ & $\ldots$ & $\ldots$ & $\ldots$ & $\ldots$ & $\ldots$ \\
\hline \multicolumn{13}{|l|}{ Memorandum items: } \\
\hline Oil prices (US\$ per barrel) 1/ & 41.3 & 20.5 & 10.7 & 21.3 & -6.2 & -3.2 & 7.0 & 48.4 & 52.6 & 30.8 & 16.9 & -2.7 \\
\hline Partner country growth $2 /$ & 1.2 & 2.6 & 2.4 & 1.8 & 2.9 & 2.1 & 2.5 & 2.2 & 1.7 & 1.1 & 0.9 & 1.1 \\
\hline
\end{tabular}

Source: IMF, World Economic Outlook.

1/ Crude Oil (petroleum), simple average of three spot prices; Dated Brent, West Texas Intermediate, and the Dubai Fateh, US\$ per barrel.

2/Real GDP growth (France, Germany, Netherlands).

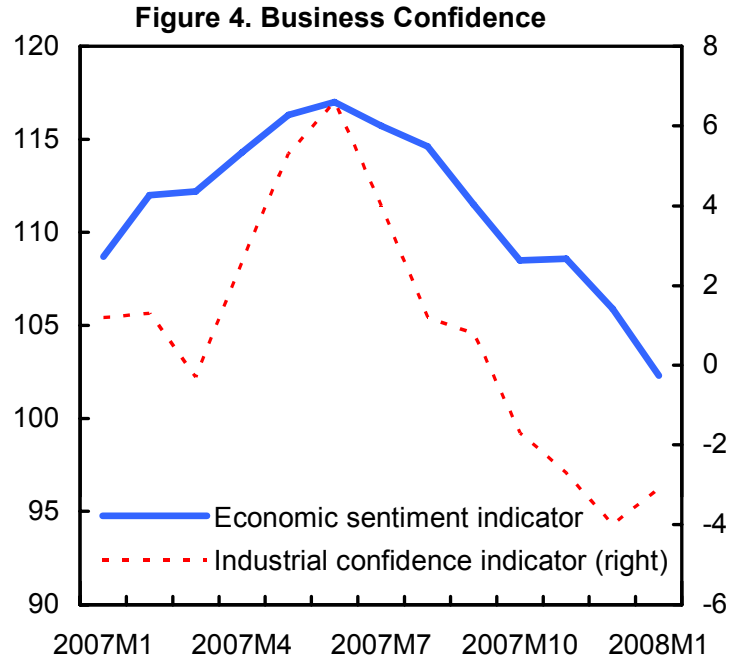

Source: National Bank of Belgium
Figure 5. Residential Construction

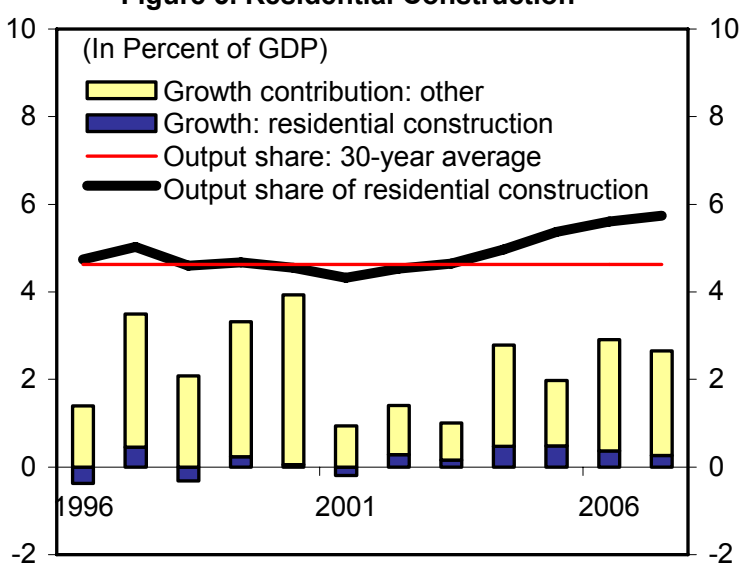

Source: National Bank of Belgium

\footnotetext{
${ }^{1}$ However, with residential construction only making up 5.7 percent of GDP in 2007, the slowdown in this sector is not a major factor.
} 
5. There was agreement that risks were tilted to the downside, but that there was no need for a policy response beyond the operation of automatic fiscal stabilizers. Oil prices, the euro appreciation and the duration of the financial turmoil are all weighing on the downside, while lack of decisive progress with domestic reforms could further sap confidence (Figure 6). The staff supported the authorities' intention to allow automatic stabilizers to operate, thus abandoning the past procyclical practice of targeting nominal balances. However, the staff cautioned that consolidation would need to resume in earnest (see Section IV.A.) and that, with widespread indexation practices (see Sections II.B and II.C), broader fiscal support to the economy could prove counterproductive.

Figure 6. Belgium: Real GDP Growth: Risks to the Forecast

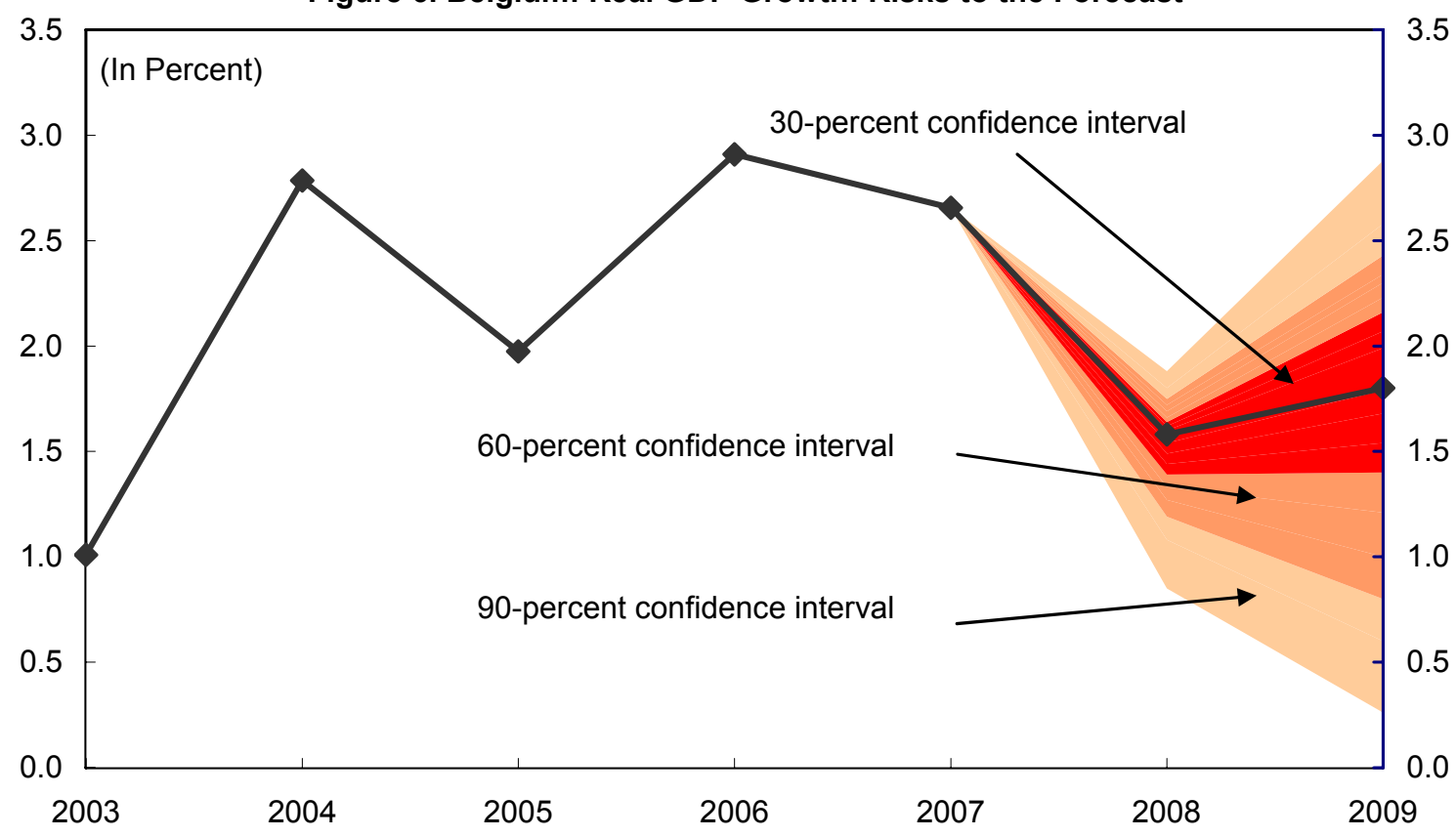

The chart includes the following risks to the baseline projections of growth (2.7 percent in 2007 and 1.6 percent in 2008):

- persistent tightening of financing conditions;

- 10 percent euro appreciation;

- 1 percent drop in foreign demand;

- boost in domestic confidence reflecting steady progress in reform agenda;

- a US recession and a disorderly unwinding of global imbalances.

They are weighted by the staff's subjective probability assessment of their occurrence.

Source: IMF staff estimates.

\section{B. How is Inflation Affecting the Economy?}

6. The factors that moderated inflation in the course of 2007 reversed toward the end of the year. The liberalization of the gas and electricity markets in Brussels and Wallonia initially reduced the consumer price of energy, exerting a moderating effect on the HICP until the summer of 2007, and allowing inflation to stay well below the average of the euro area. However, subsequently, the sharp increase in energy and food prices pushed inflation up to 3.1 percent in December 2007. 


\section{Inflation is expected to peak in early $\mathbf{2 0 0 8}$ and recede in the course of the year} (Figures 7 and 8). Even though energy and food markets are likely to stabilize, base effects and increases in the distribution margins in the energy sector in January will keep inflation high during the first quarter of 2008 . Thereafter, inflation is projected to decline gradually to around 2 percent by year-end, but the year average will register about 2.9 percent.

Figure 7. Headline Inflation

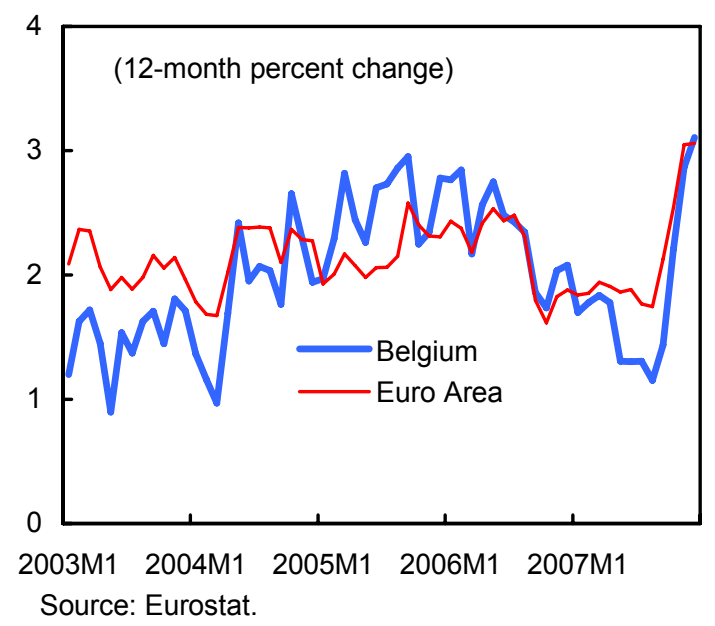

Figure 8. Contribution to Inflation 1/

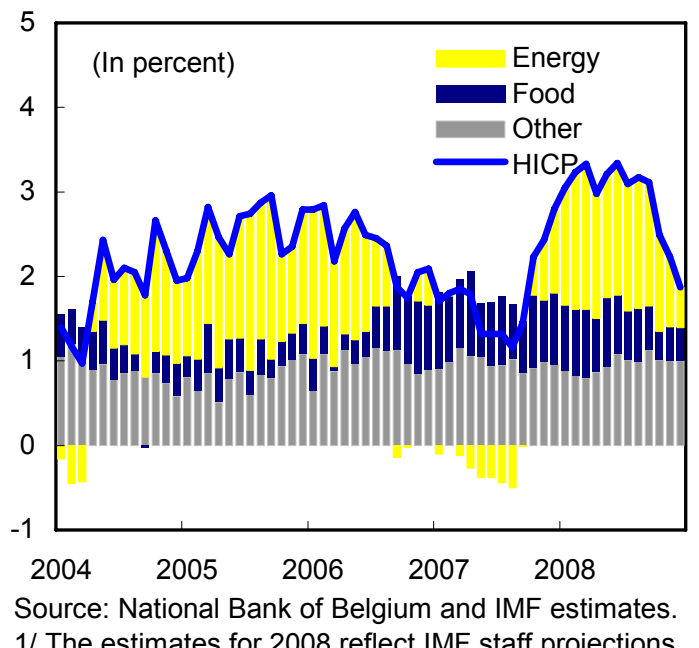

\section{Low-income groups are being disproportionately affected by the food and} energy price increases, triggering a necessary increase in targeted income support. With consumption patterns varying according to the income level of the household, a study by the central bank (NBB) shows that lower-income households suffer greater loss of purchasing power when these components register above average increases. This was observed between 2004 and 2006 (Text Table 2), and is again applicable since September 2007. Hence, the authorities have increased the subsidies to low-income households for purchases of heating oil, through a mechanism that is generally well targeted and whose budgetary implications are capped.

Text Table 2. Inflation Impact on Lowest Income Group

\begin{tabular}{lrrrr}
\hline & $1997-$ & $1999-$ & $2004-$ & \\
& 1998 & 2003 & 2006 & 2007 \\
\hline Inflation & 2.4 & 9.7 & 6.9 & 1.8 \\
Inflation first decile & 2.9 & 8.8 & 7.8 & 2.0 \\
Implicit gain (+)/loss (-) in purchasing & & & & \\
power for lower income & -0.5 & 0.8 & -0.9 & -0.2 \\
\hline
\end{tabular}

Source: National Bank of Belgium 
9. More general income support measures would not be justified, especially since existing partial indexation practices already hold up purchasing power. Public and private sector wages are indexed to a core inflation index, the so-called "health index," though some increases are subject to a lower cap. These mechanisms will boost wages by 3 percent in 2008. Even so, against the background of tight labor markets, there are calls for further wage increases. The mission cautioned against broader wage increases, which would evoke past episodes of mishandled supply shocks and subsequent painful adjustment. In line with the tradition of responsible wage bargaining and mindful of the risks to competitiveness, labor union leaders emphasized the need to stick to existing wage agreements, though they recognized that recent price increases had raised social tensions. Meanwhile, the authorities indicated that they had no intention to provide broad income support and would consider the mission's advice to seek ways to contain prices by further promoting competition, especially in the retail sector, and reviewing the distribution margins in the energy sector.

\section{Is Competitiveness an Issue?}

\section{The authorities agreed that various indicators suggest that the current level of} the real effective exchange rate is broadly appropriate. Export performance remains relatively robust, with the trend decline in export shares, except for a brief episode in 2006, fully in line with what is to be expected from the mature structure of the economy. Based on the CGER methodology, staff estimates of the REER range between a 2 percent undervaluation (reduced-form estimation) and a 4 percent overvaluation (external sustainability approach). The former approach evaluates the difference between the current REER and an equilibrium REER derived from a panel regression in which fundamental determinants of the REER are evaluated at their trend levels. ${ }^{2}$ The latter approach verifies whether on the basis of current trade elasticities, the actual exchange rate is consistent with maintaining a benchmark level of net foreign assets as a share of GDP, here chosen to be the 2006 level.

11. Current and trade accounts have been recording a steady surplus. The current account surplus reflects net savings of the private sector, more than offsetting public sector deficits. This is driven by high corporate savings, while Ricardian equivalence considerations have led to a decline in household savings (Text Table 3 ). ${ }^{3}$

\footnotetext{
${ }^{2}$ For Belgium, the relevant fundamental variables are: relative productivity, the net foreign asset position, the terms of trade, and government consumption. For details, see Methodology of CGER Assessments www.imf.org/external/np/pp/eng/2006/110806.pdf.

${ }^{3}$ The government's fiscal consolidation led individuals to lower their saving rate (see e.g. J. C. Cuaresma, and G. Reitschuler, 2007, "Is the Ricardian Equivalence Proposition an 'Aerie Fairy' Theory for Europe?"

Economica, 74).
} 
Text Table 3 . Belgium: Saving-Investment Balances (in percent of GDP)

\begin{tabular}{lrrrrrr}
\hline & 2002 & 2003 & 2004 & 2005 & 2006 & 2007 Est. \\
\hline Private savings & 24.0 & 23.3 & 23.7 & 23.8 & 24.9 & 26.0 \\
Private investment & 17.6 & 17.1 & 18.1 & 18.6 & 19.1 & 19.2 \\
Private saving surplus & 6.4 & 6.1 & 5.6 & 5.2 & 5.8 & 6.8 \\
Government saving surplus & -1.7 & -1.7 & -1.7 & -1.8 & -1.7 & -2.1 \\
National saving surplus & 4.7 & 4.4 & 3.9 & 3.4 & 4.1 & 4.7 \\
\hline
\end{tabular}

Source: IMF staff estimates.

\section{Investment in Belgium remains attractive, but the high level of labor costs} underscores the importance of preserving competitiveness through wage moderation. The authorities have eased business regulation and cut corporate income taxes, thereby supporting corporate profitability. Moreover, the 2007-08 wage agreements planned to keep wage growth well below key trading partners. However, higher-than-expected inflation will trigger wage indexation in 2008 and lift wages above the envisaged path. Hence, labor costs will evolve in line with partner countries, albeit from a higher starting level. Consequently, additional wage moderation will be necessary, though the extent of the recent REER appreciation would be smaller with more up-to-date weights (Figure 9, Text Table 4). Continuing labor and product market reforms would also help boost productivity (Section V).

Figure 9. Belgium: Competitiveness Indicators
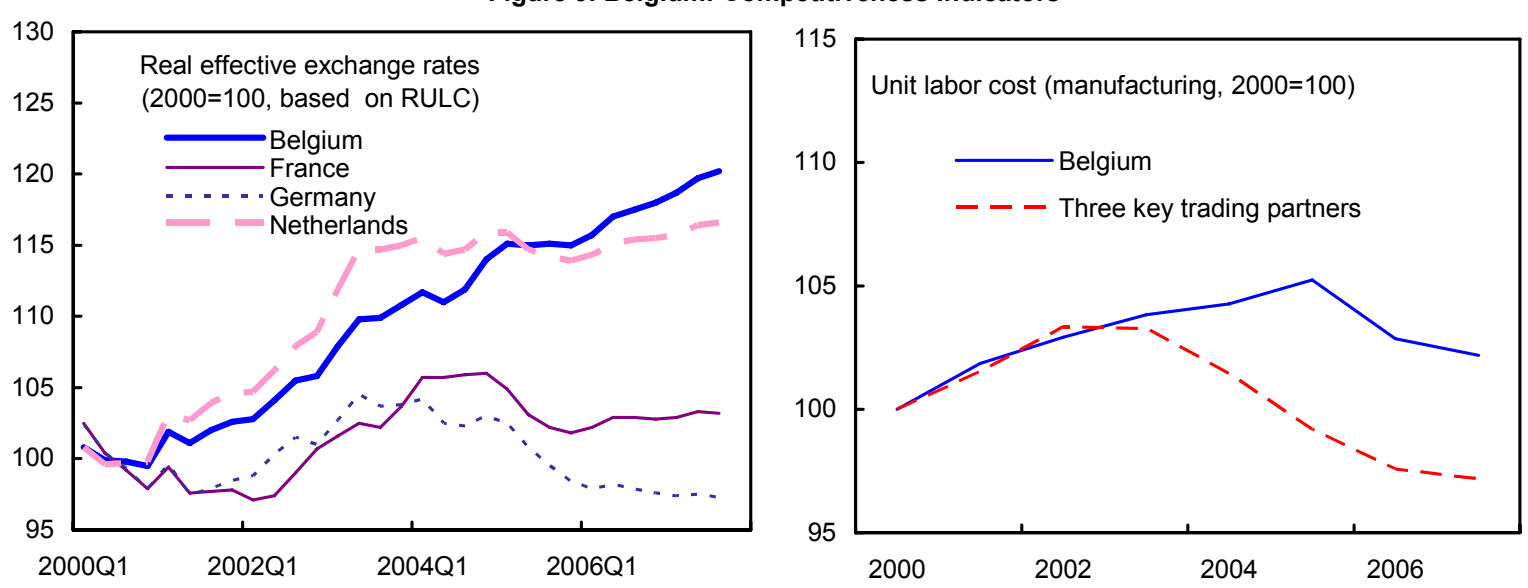

Sources: IMF, DOT, IFS, and WEO; and OECD, Economic Outlook. 
Text Table 4. Belgium: Unit Labor Costs in the Private Sector, 2003-08 (Percentage change from previous year, adjusted for seasonal and calendar effects)

\begin{tabular}{lrrrrrr}
\hline & 2003 & 2004 & 2005 & 2006 & 2007 & 2008 \\
\hline Gross wages per hour worked & $\mathbf{2 . 1}$ & $\mathbf{2 . 5}$ & $\mathbf{2 . 4}$ & $\mathbf{3 . 3}$ & $\mathbf{2 . 4}$ & $\mathbf{3 . 0}$ \\
Collectively-agreed wages 1/ & 1.9 & 2.4 & 2.3 & 2.3 & 1.9 & 2.7 \\
$\quad$ Agreed real wage increases & 0.4 & 1.0 & 0.3 & 0.5 & 0.2 & 0.6 \\
$\quad$ Indexations & 1.5 & 1.4 & 2.0 & 1.8 & 1.6 & 2.1 \\
Wage drift 2/ & 0.2 & 0.1 & 0.1 & 1.0 & 0.5 & 0.3 \\
Employers' social security contributions 3/ & 0.0 & -0.1 & -0.5 & -0.1 & 0.0 & 0.0 \\
Labor costs per hour worked & $\mathbf{2 . 1}$ & $\mathbf{2 . 4}$ & $\mathbf{1 . 9}$ & $\mathbf{3 . 2}$ & $\mathbf{2 . 4}$ & $\mathbf{3 . 0}$ \\
$\quad$ In France, Germany, and the Netherlands & 3.2 & 1.9 & 1.7 & 2.3 & 2.5 & 3.3 \\
Labor productivity 4/ & 2.1 & 2.3 & 1.1 & 1.6 & 1.1 & 1.1 \\
Unit labor costs & $\mathbf{0 . 0}$ & $\mathbf{0 . 1}$ & $\mathbf{0 . 8}$ & $\mathbf{1 . 6}$ & $\mathbf{1 . 3}$ & $\mathbf{1 . 9}$ \\
\hline
\end{tabular}

Source: Belgian authorities and IMF staff estimates and projections.

1/ Wage increases fixed by Interprofessional Wage Agreements (IPA).

2/ Resulting from increases and bonuses granted by firms, as well as from changes in employment structures.

$3 /$ Contribution to changes in labor costs.

4/ Private sector value added per hour.

\section{Financial Sector: Addressing Turbulence And EnHANCING Stability}

\section{A. How is the Financial System Coping with Financial Turbulence?}

\section{The impact on the financial sector of the ongoing financial turbulence appears}

manageable. The balance sheets of the major banks have deteriorated since mid-2007 and synthetic credit default insurance spreads have risen significantly in response to the global financial problems (Figure 10). However, strains appear to be smaller than in other major markets, although they vary from bank to bank. Bank exposure to subprime mortgages is limited to less than 1 percent of total assets and credit risk stress tests for subprime-related exposures do not result in a significant impact. Although the size of current financial vulnerabilities is inevitably subject to much uncertainty and differs by bank, estimated exposures to asset-backed securities (ABS) and collateralized debt obligations (CDO) also appear moderate. ABCP conduits sponsored by some of the largest banks have experienced difficulties in rolling over maturing commercial paper and some banks have brought these vehicles back on their books, but their size is small compared to the banks' total on-balance sheet assets.

\section{Despite some write-offs related to the financial turmoil, supervisors judged the}

financial system to have remained sound. Banks remain well capitalized, and solvency and coverage ratios of insurance companies and pension funds have been increasing. Participation in ECB liquidity operations does not seem to have been affected by the financial turmoil, and in response to the stress in financial markets, banks have taken liquidity-enhancing measures and reinforced contingency funding plans and liquidity 
Figure 10. Belgium: Financial Indicators
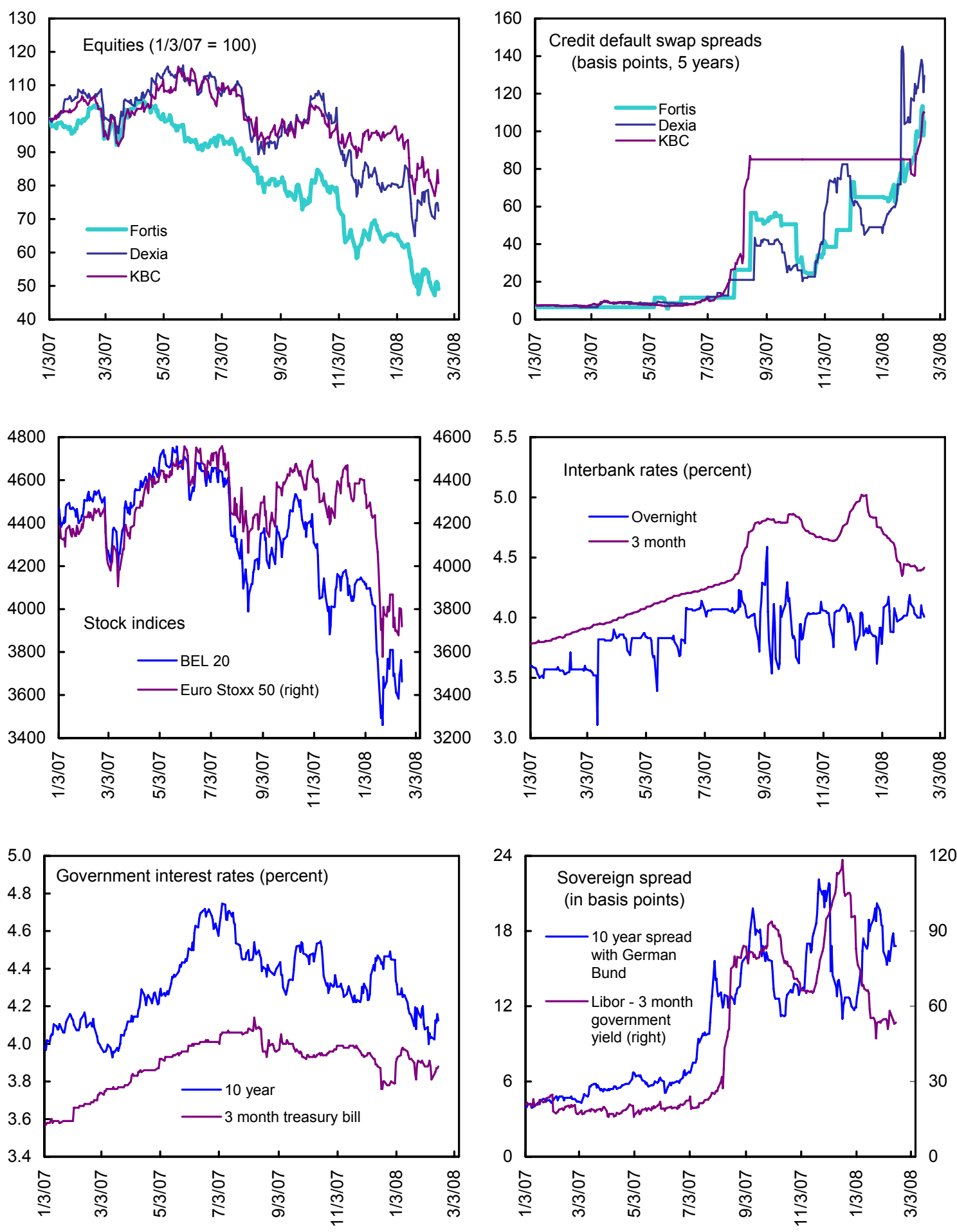

Sources: Thomson Financial/DataStream and Bloomberg. 
contingency procedures. Moreover, banks' vulnerability to liquidity shocks is mitigated by the traditionally large costumer deposit base relative to the loan book, and the presence of a large securities portfolio, which can be deployed to obtain secured financing in wholesale markets. Exposure to emerging markets is modest at less than 4 percent of total assets.

\section{Nonetheless, recent volatility in equity prices of financial institutions indicates} the need for more transparent disclosure of exposures and their implications for banks' earnings and capital. Recent actions taken by some banks to consolidate off-balance sheet exposures, albeit generally not large, generated unease about banks' earnings, even while the adverse impact of the turbulence on profitability and balance sheets of financial institutions appears manageable. Supervisory authorities agreed that early and clear disclosure of exposure by financial institutions and their valuation assumptions and methods would help ease such concerns and were actively encouraging financial institutions to improve transparency. Nevertheless, valuation remained a difficult task and volatile market conditions were likely to persist for some time. The authorities also support an international tier to supervision for regionally and globally systemic institutions and coordinated efforts to address and prevent further financial turbulence.

\section{B. Will Financial Strains Impact the Real Economy?}

16. Repercussions of the financial turbulence on the real economy have so far been limited. In contrast to the tightening credit standards in the euro area as a whole, there is no tightening trend in the lending criteria applied by Belgian banks (Figure 11). Bank credit demand by non-financial corporate firms increased in late 2007 and was expected to stabilize in early 2008. Household appetite for credit was robust in late 2007 and anticipated to hold up in early 2008, despite a slowdown in the mortgage market. At the same time, banks remained cautious about lending prospects, noting the adverse impact of the financial turbulence on their balance sheets. The authorities agreed that continued turbulence in financial markets but, more importantly, a severe and protracted slowdown of economic activity, could strain the financial sector's balance sheets, with repercussion for credit conditions.

17. The high personal savings ratio and low household leverage provide a buffer to financial turbulence, but not complete insulation. Gross financial assets of the household sector amount to over 400 percent of gross disposable income compared to financial liabilities of around 80 percent, contributing to one of the highest levels of accumulated net worth in industrialized countries. At the same time, the household sector has sharply increased its borrowing in recent years, lifted by a buoyant mortgage market. With housing and equity prices moderating, net wealth creation is expected to slow down. In addition, households have been increasing their claims on institutional investors, raising the risk profile of household assets. Hence, while households do not appear overly sensitive to credit 
Figure 11. Belgium: Bank Lending Survey Data
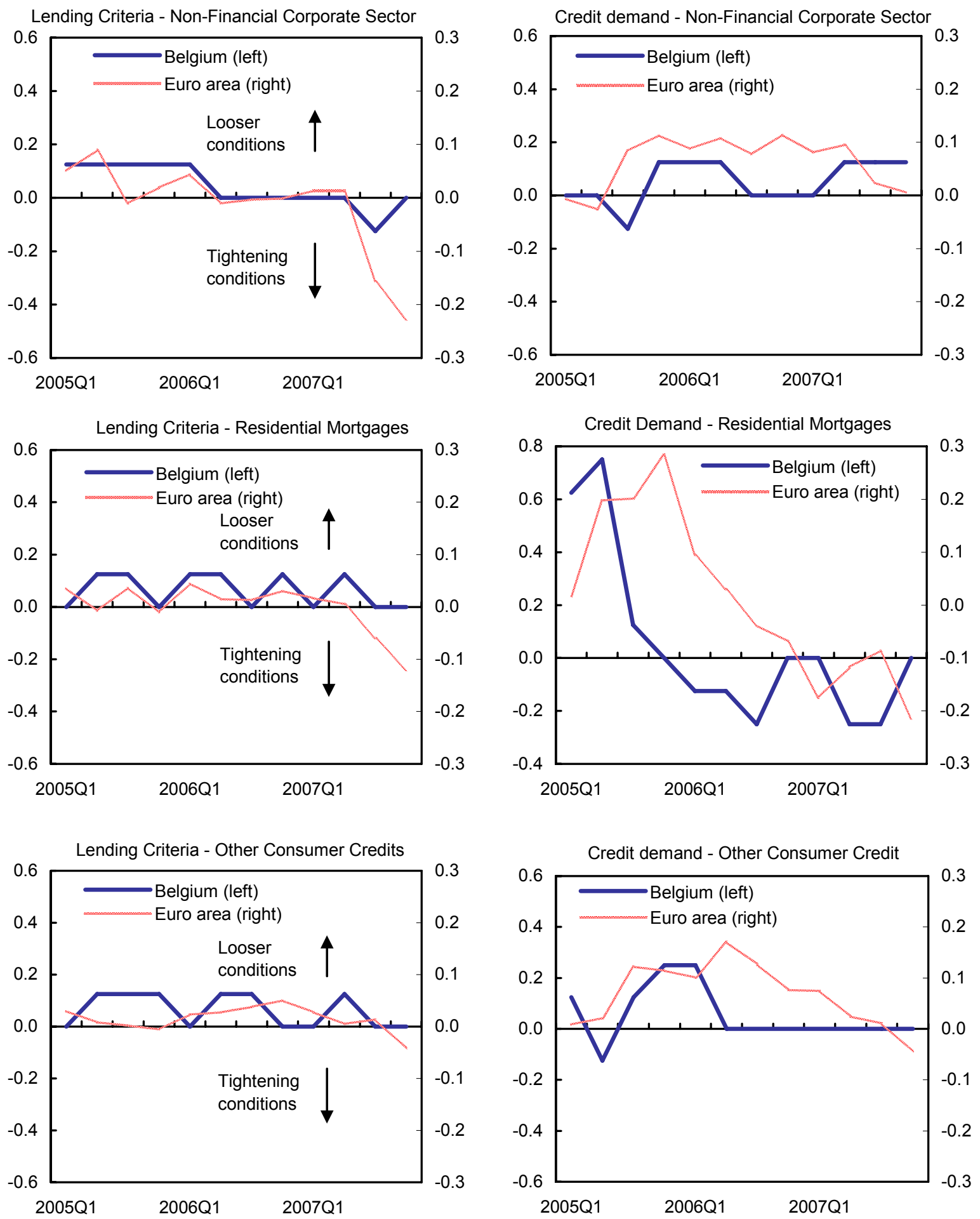

Source: National Bank of Belgium. 
conditions, financial turbulence has raised uncertainty about household real incomes. With the sensitivity of private consumption to changes in real income comparatively high in Belgium, a slowdown in private demand is likely.

18. The deleveraging of the corporate sector has reduced debt-financing risks in the short term. Profit margins of nonfinancial corporations continued to rise through mid-2007, allowing internal funds to finance investment. Similarly, with the implementation of the notional interest rate deduction for corporate equity in 2006, equity financing exploded. The corporate sector's healthy balance sheets suggest resilience to a credit squeeze. However, the financial turbulence-induced slowdown in domestic and global demand is likely to pressure profit margins and delay investment plans.

\section{How Can Financial Stability be Further Enhanced?}

19. Commendable progress has been made in enhancing the effectiveness of the prudential supervision, helping to safeguard financial stability. In line with the 2005 FSAP recommendations, the supervisory framework is being continuously upgraded. The management committee of the Banking, Insurance and Finance Commission (CBFA) has been streamlined and synergies between the CBFA and the central bank (NBB) have been further developed. Regular stress tests have helped promote a systematic dialogue between supervisory authorities and market participants, while a thorough test of detailed procedures for financial crisis management yielded a satisfactory outcome. Prudential supervision of the insurance sector has been upgraded and regulation of the pension funds sector reinforced.

\section{At the same time, financial innovations and cross-border consolidation are} modifying the financial landscape considerably. Given the increasing sophistication of financial instruments and the complexity of bancassurance conglomerates, the authorities are well aware of the need to remain vigilant and ensure that their capacity to identify risks keep pace with market developments. To help limit the adverse effects of the ongoing financial turbulence, they favor more disclosure of exposures, risks, and valuation assumptions and methodologies. The staff noted that with the cross-border dimension of the financial system continuing to gain importance, especially following the recent Fortis-ABN AMRO transaction, deeper coordination with host country authorities will be needed. 


\section{Fiscal Policy: Resuming Consolidation AND IMPRoving Institutions}

\section{A. Why has Fiscal Consolidation Become an Urgent Priority?}

21. Fiscal adjustment should be at the core of a comprehensive strategy to address the projected rise in aging-related costs. Population aging will raise public expenditures by close to 6 percentage points of GDP by 2050 (Figure 12). In the absence of fiscal adjustment, the public debt-to-GDP ratio is set to move onto an unsustainable path. There is broad public support for a significant pre-funding of the rise in agingrelated spending, reflecting concerns about intergenerational fairness and the need to avoid activity-discouraging tax increases or drastic spending cuts in the future. This strategy, as carefully articulated by the High Finance Council (HFC), consists of building surpluses gradually and using the savings from declining public debt to finance part of the costs of aging (Figure 13). Durable primary expenditure restraint will be needed to deliver the required primary surpluses as Belgium's revenue-to-GDP ratio - close to 50 percent of GDP - is already very high. Ideally, spending should be lowered even further to allow a reduction in the tax burden on labor, which would help job creation, as would growth-enhancing policies and entitlement reforms.

\section{Initially planned to begin in 2007 , fiscal consolidation has slipped below the HFC's} planned surplus of 0.3 percent of GDP (Text Table 5). The authorities stressed that fiscal slippage was mostly due to the hiatus in policy making since April 2007, albeit partly offset by higher revenue reflecting higher-than-anticipated economic growth. In addition, with the elimination of one-off measures, fiscal policy was broadly neutral, with the structural balance remaining close to balance. However, on current policies, the fiscal position is set to deteriorate, raising concerns about medium and long-term sustainability (Figure 14). In this context, the authorities recognized that fiscal consolidation is a priority to address the projected rise in aging-related costs. 
Text Table 5. Belgium: General Government Fiscal Indicators, 2003-2009

(In percent of GDP, unless otherwise indicated)

\begin{tabular}{lrrrrrrr}
\hline & & & & \multicolumn{3}{c}{ Est. } & \multicolumn{3}{c}{ Proj. 1/ } \\
\cline { 7 - 9 } & 2003 & 2004 & 2005 & 2006 & 2007 & 2008 & 2009 \\
\hline General government balance 2l & 0.0 & 0.0 & -2.3 & 0.4 & -0.1 & -0.5 & -0.5 \\
$\quad$ Nonstructural measures & 1.2 & 0.8 & -2.0 & 0.7 & -0.1 & -0.1 & 0.0 \\
Structural balance & -1.0 & -0.6 & 0.4 & -0.1 & -0.1 & -0.2 & -0.2 \\
$\quad$ Interest charges & 5.3 & 4.7 & 4.2 & 4.0 & 3.8 & 3.7 & 3.5 \\
Structural primary balance & 4.3 & 4.2 & 4.5 & 3.8 & 3.8 & 3.5 & 3.3 \\
Change in structural balance & -0.8 & 0.5 & 0.9 & -0.5 & 0.1 & -0.1 & 0.0 \\
Public debt 2/ & 98.7 & 94.4 & 92.2 & 88.1 & 84.5 & 81.7 & 79.2 \\
Memorandum items: & & & & & & & \\
$\quad$ Real primary spending growth (in percent) 2/ & 4.9 & -0.2 & 8.9 & -3.7 & 3.7 & 2.0 & 2.0 \\
$\quad$ Real GDP growth & 1.0 & 2.8 & 2.0 & 2.9 & 2.7 & 1.6 & 1.8 \\
\hline
\end{tabular}

Sources: National Bank of Belgium; and IMF staff.

1/ Based on unchanged policy assumption.

2/ Assumes Eurostat's treatment of the national railway company debt transfer in 2005.

23. The authorities are committed to resuming structural fiscal adjustment in 2008 .

Staff stressed the need for a significant effort so as to restore the credibility of their commitment to fiscal consolidation. However, given that only a provisional budget has been in place in the first quarter of 2008, reaching a surplus of $1 / 2$ percent of GDP already this year, as envisaged under the HFC-recommended scenario, appears to be unrealistic. Targeting a structural improvement of $1 / 2$ percent of GDP in 2008 would seem to strike the right balance with feasibility. It is consistent with the prescription of the Stability and Growth Pact for countries that have not yet reached their medium-term objectives, and would bolster confidence in economic policies, especially

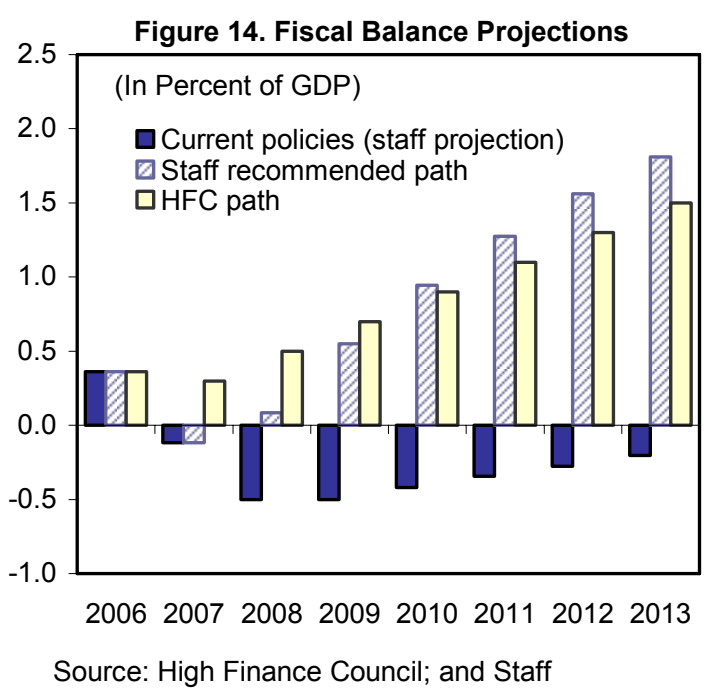
important now that other sources of uncertainty cloud the outlook. On the basis of the authorities' macroeconomic assumptions, this approach would imply a nominal budget surplus of nearly 0.2 percent of GDP. The authorities responded they would try to achieve a small surplus, though this would be difficult, and emphasized that balancing the budget in nominal terms in 2008 was their minimum objective. At the same time, they conceded that uncertainty regarding constitutional reform and the political economy of the 2009 regional elections posed significant risks for fiscal consolidation.

24. The authorities are focused on using structural measures to deliver the required consolidation, while avoiding recourse to one-off measures. They agreed that such 
measures only postponed the needed adjustment and often constitute non-transparent claims on future resources. For the same reason, staff emphasized that public-private partnerships should not be used to circumvent fiscal adjustment needs. Risks and future spending obligations related to such arrangements should be reported in a transparent way.

\section{Delivering the envisaged structural adjustment requires a concerted effort at all}

levels of government. The authorities agreed that there is little room for new spending initiatives or tax cuts, absent compensation elsewhere within the tighter budget envelope, though various coalitions partners remained to be convinced. At the same time, the high tax pressure, especially on labor, also rules out further increases in the overall tax burden. Hence, the adjustment will need to focus on expenditure restraint, for which the following will be essential:

- $\quad$ Any savings from a declining interest bill will have to be set aside.

- $\quad$ Regions and communities will need to contribute more than envisaged in the budgets adopted for 2008. Sustaining a surplus of at least 0.3 percent of GDP, as was achieved in 2007, seems feasible (Text Table 6). In the staff's view, such an objective is justified because commitments to future spending have increased under publicprivate partnerships, and the resolution of vertical imbalances in the fiscal federalism arrangements will require a devolution of competencies and associated spending to the regions without a proportional transfer of revenues. However, some regions disagree with this approach and seek further transfers from the federal level.

- $\quad$ The social security surplus should be maintained at its current level (about 0.5 percent of GDP). The authorities agreed that the rise in health care spending could be kept in line with trend-GDP growth without compromising the high quality of the health care system.

- Similarly, there is scope to slow the pace of spending growth on priority items in the federal budget compared to existing plans, and curb other discretionary spending, e.g., by streamlining functions across levels of government, deriving efficiency gains from upcoming retirements from the civil service, outsourcing of activities, and cutting subsidies.

- In addition, subsidies (including tax expenditure) for key items rose by $1 / 2$ percentage point of GDP over the past five years. Partly reversing this process (e.g., by lowering the subsidies for service vouchers) will help fiscal adjustment and raise efficiency and fairness. Moreover, tax exemptions (e.g., on some savings instruments) can usefully be tightened. 
Text Table 6. Belgium: Fiscal Accounts by Level of Government, 2002-2007 1/ (In percent of GDP)

\begin{tabular}{|c|c|c|c|c|c|c|}
\hline & 2002 & 2003 & 2004 & 2005 & 2006 & $\begin{array}{r}2007 \\
\text { Est }\end{array}$ \\
\hline \multicolumn{7}{|l|}{ Revenue } \\
\hline Federal & 13.1 & 13.9 & 11.5 & 11.7 & 11.2 & 10.7 \\
\hline Social security & 18.8 & 18.7 & 19.3 & 19.2 & 19.2 & 19.5 \\
\hline Local government & 6.5 & 6.9 & 6.6 & 6.7 & 6.6 & 6.6 \\
\hline Regions and communities & 11.4 & 11.7 & 11.7 & 11.7 & 11.7 & 11.8 \\
\hline \multicolumn{7}{|l|}{ Primary expenditure } \\
\hline Federal & 8.0 & 8.7 & 7.3 & 10.3 & 7.5 & 8.1 \\
\hline Social security & 18.3 & 18.9 & 19.3 & 19.2 & 18.9 & 18.9 \\
\hline Local government & 6.5 & 6.7 & 6.5 & 6.6 & 6.7 & 6.5 \\
\hline Regions and communities & 11.3 & 11.5 & 11.3 & 11.3 & 11.3 & 11.4 \\
\hline \multicolumn{7}{|l|}{ Balance } \\
\hline Federal & -0.2 & 0.3 & -0.1 & -2.4 & 0.1 & -0.9 \\
\hline Social security & 0.5 & -0.3 & 0.1 & 0.0 & 0.3 & 0.5 \\
\hline Local government & -0.2 & -0.1 & -0.2 & -0.1 & -0.2 & 0.0 \\
\hline Regions and communities & -0.1 & 0.0 & 0.2 & 0.3 & 0.2 & 0.3 \\
\hline
\end{tabular}

Sources: National Bank of Belgium; and IMF staff.

1/ Follows Eurostat's definition of the national railway company debt transfer in 2005.

26. Fiscal adjustment over the medium term will need to make up for the recent slippage. The authorities argued that the measures adopted in the 2008 budget together with upcoming reforms to fiscal federalism arrangements should set in motion sufficient adjustment to deliver the HFC-recommended surplus of 1.1 percent of GDP by 2011, consistent with a primary structural surplus of close to $4 \frac{1}{2}$ percent of GDP. Staff noted, however, that future surpluses will need to exceed this path to make up for the recent slippage and catch up with the required reduction in public debt. Interest savings from favorable debt dynamics will then bring about further increases in nominal surpluses.

27. More generally, refocusing the fiscal framework on a medium-term path for the primary surplus will allow to anchor sustainable fiscal consolidation. The authorities noted that moving away from a nominal budget target could complicate public communication and accountability, but agreed that a multi-year expenditure framework would help guide the annual budget process, including through the careful costing of initiatives within a multi-year budgetary envelope. In addition, a performance-oriented approach to budgeting should help increase efficiency and the effectiveness of public services. 


\section{B. Why is There a Need to Revise Fiscal Federalism Arrangements?}

\section{The current fiscal federalism arrangements have led to unsustainable fiscal} imbalances among different levels of government. Current expenditure and revenue assignments will result in widening imbalances between the federal institutions (federal government and social security, the so-called "Entity I") and regional and local governments (the so-called "Entity II," Figure 15). With most of the increase in aging-related spending projected to fall on Entity I, the federal entities will have to bear the brunt of the adjustment, likely leading to an unsustainable squeeze in expenditure growth at the federal level. Entity II will need to share more of the adjustment burden in the context of changes in the fiscal federalism arrangements, possibly through a shift of some aging-related expenditure responsibilities from Entity I to Entity II. The authorities agreed that such a shift would be necessary and that regional entities would need to become fully accountable for any

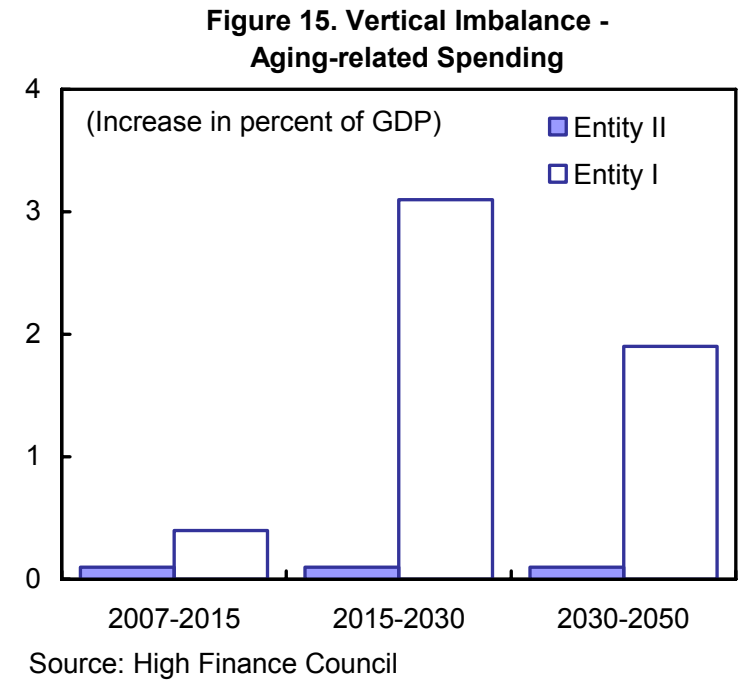
decisions that impact the social security system. In addition, strengthening the municipalities' accountability for their budgetary decisions was also necessary. The authorities hoped to be able to build a consensus to solve these vertical imbalances in the next few months.

\section{Current fiscal federalism arrangements also feature horizontal imbalances} within Entity II. These imbalances reflect regional income and growth differentials due to the linking of the distribution of part of intergovernmental revenue sharing to the growth of personal income tax revenues (Figure 16). While tempered by an equalization scheme and expected to evolve as regional growth patterns change, horizontal imbalances raise equity, incentive, and solidarity concerns, adding another layer of complexity to reaching agreement on population-aging burden sharing. A broad consensus will have to guide their resolution. It will be essential that any new agreements be

Figure 16. Horizontal Imbalance - Tax Revenue

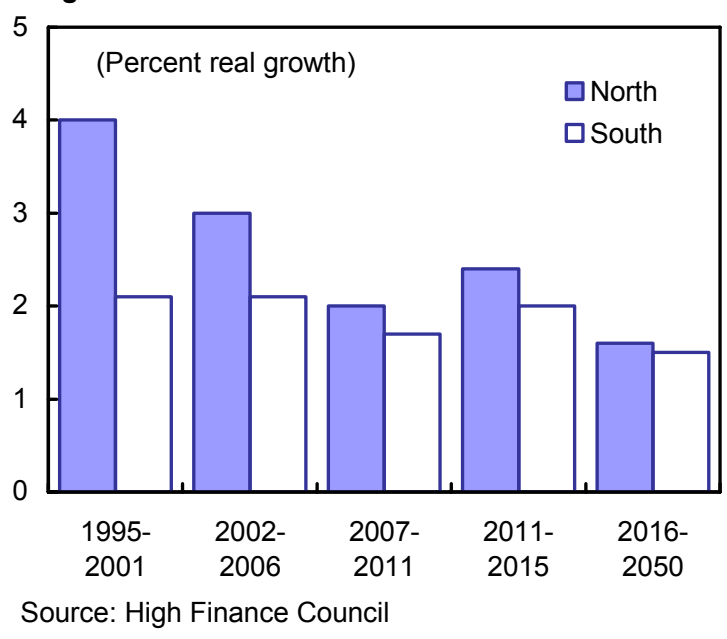
neutral from a consolidated budget perspective, provide incentives for regions to work toward narrowing income differences, and are fully transparent about the intergovernmental solidarity mechanisms. 


\section{Successful medium-term adjustment will also require greater accountability,} more transparency, and stronger coordination among government entities. The arrangements to coordinate fiscal policy between levels of government centered on the High Finance Council overall have been effective, but could be further strengthened. To avoid a hiatus in these arrangements in periods of political uncertainty, targets for the different levels of government could be fixed for a rolling multi-year horizon, which would facilitate medium-term expenditure planning, and be embedded in published internal stability pacts. The role of the High Finance Council could be reinforced and expanded through a mandate that includes an assessment of compliance with the internal stability pact at the stage of budget submission to parliament, and through a strengthening of the analytic capacity of the HFC. The authorities agreed that further devolution of competencies would necessitate strengthening of coordination and accountability for budgetary and other economic policies, but there was no agreement yet on what mechanism to put in place.

\section{Structural Reforms: Raising Employment And Productivity}

\section{Pressing ahead with structural reforms, especially in the labor market, is key to} preserving high living standards. Without further reforms, demographic trends will dampen long-term growth, as population aging curbs labor supply and sharply raises dependency ratios. Despite recent increases, employment rates remain among the lowest in the industrialized world, especially among older and low-skilled workers (Figure 17). While some areas of the country are close to full employment, others are mired in high unemployment, contributing to geographical differences in growth and income. In addition, labor market participation is low throughout the country, underscoring fundamental skill mismatches and limited labor mobility.

Figure 17. Employment and Unemployment

Employment remains below the OECD average

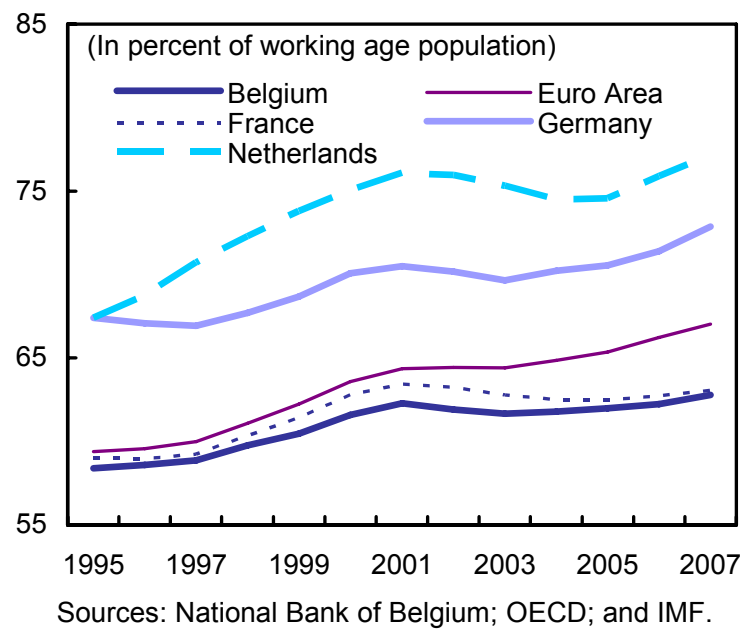

Unemployment is high with stark regional differences

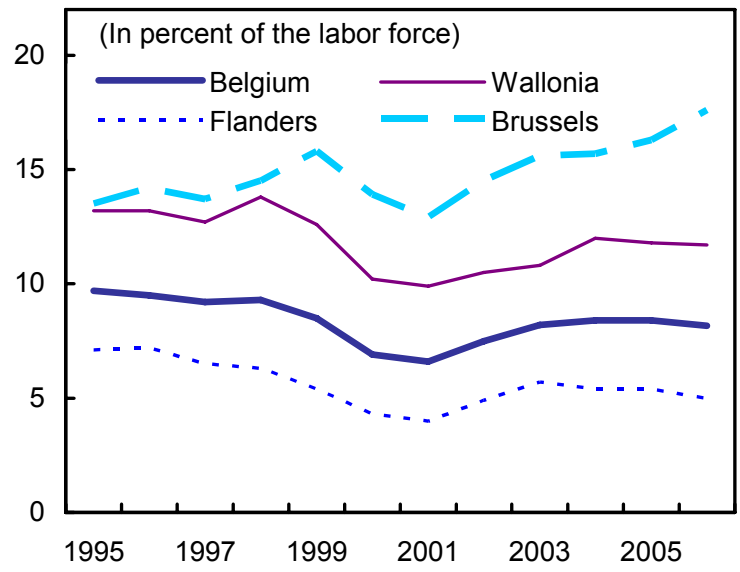




\section{To sustain good rates of job creation, further labor market reforms will be} essential. The spotlight on activation policies (i.e., enforcing job search requirements and providing job search assistance) has been appropriate, and has taken advantage of the until recently buoyant economy. Nonetheless, better tailoring of labor market policies to regional needs and coordination across regions and sub-regions is necessary to raise their effectiveness. Consensus is lacking for a new round of comprehensive labor market reforms, though most stakeholders agree on the need to further improve labor market performance. Specifically, labor market reforms should involve:

- $\quad$ Raising investment in human capital. There is broad agreement that the pursuit of ongoing initiatives with respect to $\mathrm{R} \& \mathrm{D}$, the further strengthening of programs for on-the-job and life-long training, and an increase in the efficiency of secondary and higher education are likely to pay off handsomely in terms of the economy's ability to adopt new technologies, attract foreign investment, and maintain comparatively high living standards.

- $\quad$ Removing inactivity traps and keeping older workers in the labor force. To achieve the first, a comprehensive review of the tax-benefit system would be useful, but parts of the political spectrum and labor unions are adverse to lowering or taxing benefits. In line with OECD recommendations, a balanced reform could consist of the phasing out of unemployment benefits - virtually all other industrialized countries have strict time limits and phased benefits - in exchange for an increase in payouts during the first few months of unemployment. It could be accompanied by the inclusion of all out-of-work benefits and allowances in taxable income, in exchange for a gradual, rather than immediate removal of these benefits when jobs are taken up. Alternatively, a higher earned income tax credit could be considered. Such an approach would reap the synergies between fiscal adjustment and labor market polices. To help raise employment rates of older workers, the planned extension of activation policies to these workers is welcome, but it will need to be complemented by a complete phasing out of early retirement regimes.

- $\quad$ Sustaining wage moderation and increasing wage flexibility. While the central wage-bargaining framework is likely to continue to maintain wage moderation, shifting its focus from job preservation to job creation would improve labor market outcomes. To take better account of productivity differentials between regions, sectors, and enterprises, and foster a dynamic reallocation of workers to new activities, the practice of "all-in" wage agreements should be extended and larger margins for wage differentiation allowed. Social partners, however, do not see a need for any significant changes to the current wage-bargaining framework.

33. More competition in product markets will boost productivity. The authorities agreed that continuing the reduction in the administrative burden on businesses and households, and the swift implementation of EU directives regarding market liberalization 
and the removal of obstacles to competition would raise efficiency. They indicated that progress in this area had fallen victim to the hiatus in federal policy making following the June 2007 elections and suffered from lack of coordination between regional and federal levels of government. With the preoccupation about fiscal federalism reforms, they conceded that reviving attention for structural reform could take a while.

\section{Staff Appraisal}

34. With growth slowing and the window to address population aging closing rapidly, returning to an ambitious reform agenda has become urgent. Expectations a year ago that, following the June 2007 elections, a new federal government would take immediate decisive action to meet long-term challenges have not been validated. The difficulty in creating consensus around much needed fiscal federalism reforms has so far prevented the emergence of a full-fledged government and diverted attention from these priorities. However, further delays in building up fiscal surpluses and boosting employment rates and productivity cannot be afforded. Meanwhile, clarifying the direction of policies early on has become especially important now that other sources of uncertainty cloud the outlook.

\section{Addressing the cyclical downturn through automatic fiscal stabilizers is} appropriate, while the impact of partial indexation on competitiveness will require continued wage moderation. After several years of robust economic performance, growth is expected to slow significantly, mostly owing to external factors. In addition, risks are tilted to the downside. Provided fiscal consolidation is resumed, the authorities' intention to allow fiscal stabilizers to operate fully and abandon the procyclical use of one-off measures to meet nominal budget targets is welcome. Similarly, limiting the response to energy price spikes to an increase in well-targeted and capped income support for the lowest-income households is apposite. Indeed, with widespread partial indexation, broader measures would be counterproductive. Furthermore, maintaining competitiveness, which is broadly fine at its current level, will require wage moderation going forward.

\section{Maintaining a sound financial system and high-quality supervision are}

paramount. Financial institutions have remained resilient in the face of the ongoing financial turbulence, but market conditions have yet to return to normal and a stronger-thanexpected economic slowdown could prove taxing. Financial institutions therefore need to uphold capital buffers. Actions by supervisors to promote early disclosure of exposures and losses and enhanced transparency practices would be welcome as they would help dampen market volatility and underpin confidence. While already high-quality prudential supervision is being further enhanced, the relentless rise in the cross-border dimension of the financial system requires stronger coordination with host country authorities.

\section{Resuming ambitious fiscal consolidation and improving fiscal frameworks and}

federalism arrangements are urgent priorities. While there has so far been broad support for a strategy of pre-funding of the expected rise in aging costs, actual fiscal consolidation 
has slipped below the path recommended by the High Finance Council as the result of the hiatus in policy making at the federal level since April 2007. It will be important to get back on track as soon as possible:

- $\quad$ From this perspective, the intention to resume fiscal consolidation in 2008 is welcome, but a more ambitious effort, amounting to an improvement in the structural balance by $1 / 2$ percent of GDP, would better underpin credibility and bolster confidence in economic policies.

- $\quad$ Delivering the necessary structural adjustment will require a concerted effort at all levels of government. There is no room for new spending initiatives or tax cuts, while the high tax pressure, especially on labor, also rules out further increases in the overall tax burden. Expenditure restraint will thus need to be the primary source of adjustment.

- $\quad$ Refocusing the fiscal framework on a medium-term path for the primary surplus will be key to achieving consolidation objectives. The authorities' intent to avoid recourse to one off measures is welcome, as such measures often imply nontransparent claims on future resources. In the same vein, recourse to public-private partnerships, which has risen substantially recently, should be restrained.

- $\quad$ Finally, while a broad consensus will need to guide the revision of fiscal federalism arrangements, it will be important that new arrangements be neutral from a consolidated budgetary perspective, provide incentives for regions to narrow income differences, and be accompanied by strengthened accountability and stronger coordination of economic policies across all levels of government.

\section{Implementing a new round of structural reforms will be essential to reap} synergies with fiscal adjustment and achieve the much needed increase in employment rates and productivity growth. Progress in raising employment rates is evident, owing to better activation policies, while initiatives with respect to training, education and R\&D investments are likely to pay off in terms of productivity. Meanwhile, the wage bargaining framework continues to deliver wage moderation. Nonetheless, labor market performance is still lagging well behind the OECD average, and large geographical differences in unemployment rates reflect deep-rooted structural problems. Priority areas for reform are removing inactivity traps, raising low employment rates of older workers, and fostering labor mobility. Addressing these issues would generate synergies between fiscal adjustment and labor market reforms. Further goods and services markets reforms would boost productivity growth and consumer welfare.

39. It is proposed that the next Article IV consultation be held on the standard 12-month cycle. 
Table 1. Belgium: Main Economic Indicators, 2003-09

(Percentage change from previous year; unless otherwise indicated)

\begin{tabular}{|c|c|c|c|c|c|c|c|}
\hline & \multirow[b]{2}{*}{2003} & \multirow[b]{2}{*}{2004} & \multirow[b]{2}{*}{2005} & \multirow[b]{2}{*}{2006} & \multirow{2}{*}{$\begin{array}{l}\text { Est. } \\
2007\end{array}$} & \multicolumn{2}{|c|}{ Proj. } \\
\hline & & & & & & 2008 & 2009 \\
\hline \multicolumn{8}{|l|}{ Demand and output (in real terms) } \\
\hline GDP & 1.0 & 2.8 & 2.0 & 2.9 & 2.7 & 1.6 & 1.8 \\
\hline Private consumption & 0.7 & 1.4 & 1.4 & 2.1 & 2.5 & 1.5 & 1.9 \\
\hline Public consumption & 2.1 & 1.8 & -0.2 & 0.0 & 1.8 & 2.4 & 2.2 \\
\hline Gross fixed investment & -0.3 & 7.5 & 6.7 & 4.2 & 4.9 & 1.4 & 2.7 \\
\hline Of which: enterprise investment & -1.8 & 7.4 & 4.6 & 3.9 & 5.1 & 1.9 & 3.0 \\
\hline Stockbuilding $1 /$ & 0.0 & 0.2 & 0.2 & 0.8 & 0.1 & 0.0 & 0.0 \\
\hline Exports of goods and nonfactor services & 2.9 & 6.3 & 4.1 & 2.6 & 4.6 & 4.6 & 5.4 \\
\hline Imports of goods and nonfactor services & 2.8 & 6.5 & 4.9 & 2.5 & 5.0 & 5.2 & 5.4 \\
\hline Foreign balance $1 /$ & 0.2 & 0.1 & -0.5 & 0.2 & -0.1 & -0.4 & 0.1 \\
\hline Output gap (in percent of potential GDP) & -0.9 & 0.0 & -0.2 & 0.2 & 0.4 & -0.2 & -0.4 \\
\hline \multicolumn{8}{|l|}{ Labor market } \\
\hline Labor force (national definition) & 1.1 & 1.5 & 1.5 & 1.0 & 0.5 & 0.5 & 0.5 \\
\hline Employment (national definition) & 0.1 & 0.7 & 1.2 & 1.3 & 1.6 & 0.6 & 0.4 \\
\hline EU harmonized unemployment rate $2 /$ & 8.2 & 8.4 & 8.4 & 8.2 & 7.5 & 7.4 & 7.5 \\
\hline NAIRU 2/ & 7.9 & 7.9 & 7.8 & 7.7 & 7.6 & 7.5 & 7.5 \\
\hline \multicolumn{8}{|l|}{ Prices, wages, and incomes } \\
\hline GDP deflator & 1.6 & 2.4 & 2.4 & 2.0 & 1.7 & 2.4 & 2.1 \\
\hline Terms of trade (goods) & -0.4 & -0.2 & -0.5 & -0.7 & 0.8 & 0.3 & 0.0 \\
\hline Consumer price index (harmonized) & 1.5 & 1.9 & 2.5 & 2.3 & 1.8 & 2.9 & 1.9 \\
\hline Labor productivity $3 /$ & 0.9 & 2.1 & 0.7 & 1.6 & 1.1 & 1.0 & 1.4 \\
\hline \multicolumn{8}{|l|}{ Interest rates (percent) } \\
\hline Money market rate (3 month) & 2.3 & 2.1 & 2.2 & 3.1 & 4.3 & $\ldots$ & $\ldots$ \\
\hline Government bond yield & 4.2 & 4.2 & 3.4 & 3.8 & 4.3 & $\ldots$ & $\ldots$ \\
\hline \multicolumn{8}{|l|}{ Saving and investment (in percent of GDP) } \\
\hline Private saving & 23.3 & 23.7 & 23.8 & 24.9 & 25.6 & 25.4 & 25.4 \\
\hline Private investment & 17.1 & 18.1 & 18.6 & 19.1 & 19.3 & 19.1 & 19.1 \\
\hline Private saving surplus & 6.1 & 5.6 & 5.2 & 5.8 & 6.3 & 6.3 & 6.3 \\
\hline Government saving surplus & -1.7 & -1.7 & -1.8 & -1.7 & -2.1 & -2.4 & -2.4 \\
\hline National saving surplus & 4.4 & 3.9 & 3.4 & 4.1 & 4.2 & 3.9 & 3.8 \\
\hline \multicolumn{8}{|c|}{ Public finances, general government (in percent of GDP) 4/ } \\
\hline Revenue & 51.1 & 49.2 & 49.4 & 48.7 & 48.5 & 48.2 & 48.1 \\
\hline Expenditure & 51.1 & 49.2 & 51.6 & 48.4 & 48.7 & 48.7 & 48.6 \\
\hline Of which: interest on public debt & 5.3 & 4.7 & 4.2 & 4.0 & 3.8 & 3.7 & 3.6 \\
\hline Fiscal balance & 0.0 & 0.0 & -2.3 & 0.4 & -0.1 & -0.5 & -0.5 \\
\hline Primary balance & 5.3 & 4.7 & 1.9 & 4.3 & 3.7 & 3.2 & 3.0 \\
\hline Structural balance $5 /$ & -1.0 & -0.6 & 0.4 & -0.1 & -0.1 & -0.2 & -0.2 \\
\hline Gross public debt & 98.7 & 94.4 & 92.2 & 88.1 & 85.1 & 82.2 & 79.7 \\
\hline \multicolumn{8}{|l|}{ Balance of payments } \\
\hline Current account balance (in billions of euros) & 11.4 & 10.2 & 7.9 & 8.4 & 10.7 & 10.2 & 10.6 \\
\hline (In percent of GDP) & 4.1 & 3.5 & 2.6 & 2.7 & 3.2 & 3.0 & 3.0 \\
\hline Trade balance (in billions of euros) & 9.7 & 7.8 & 4.7 & 2.6 & 3.8 & 4.3 & 4.6 \\
\hline (In percent of GDP) & 3.5 & 2.7 & 1.6 & 0.8 & 1.2 & 1.3 & 1.3 \\
\hline \multicolumn{8}{|l|}{ Exchange rates } \\
\hline Nominal effective rate $(2000=100)$ & 105.7 & 106.8 & 106.9 & 107.3 & 109.1 & $\ldots$ & $\ldots$ \\
\hline Real effective rate $(2000=100) 6 /$ & 110.3 & 111.9 & 113.3 & 115.0 & 117.6 & $\ldots$ & $\ldots$ \\
\hline
\end{tabular}

Sources: Data provided by the authorities; and IMF staff estimates and projections.

$1 /$ Contribution to growth.

2/ Percent of the labor force.

3/ Based on national accounts data, for economy-wide.

4/ Includes the effect of the restructuring of the national railway company in 2005 as presented by Eurostat. 5/ Excludes effect of one-off measures, including the restructuring of the national railway company in 2005.

6 / Based on relative unit labor costs in manufacturing. 
Table 2. Belgium: Operations of the General Government, 2000-2006 1/ (In percent of GDP, unadjusted for working days)

\begin{tabular}{|c|c|c|c|c|c|c|c|}
\hline & 2000 & 2001 & 2002 & 2003 & 2004 & 2005 & 2006 \\
\hline Revenue & 49.1 & 49.6 & 49.8 & 51.1 & 49.2 & 49.4 & 48.7 \\
\hline Tax revenue & 44.4 & 44.4 & 44.7 & 44.2 & 44.5 & 44.3 & 43.9 \\
\hline Direct taxes & 17.1 & 17.3 & 17.1 & 16.7 & 16.7 & 16.9 & 16.5 \\
\hline Personal income tax & 13.6 & 14.0 & 13.9 & 13.6 & 13.3 & 13.3 & 12.6 \\
\hline Company income tax & 3.3 & 3.2 & 3.2 & 3.0 & 3.3 & 3.6 & 3.9 \\
\hline Other direct taxes & 0.1 & 0.1 & 0.1 & 0.1 & 0.1 & 0.1 & 0.1 \\
\hline Indirect taxes & 12.9 & 12.5 & 12.7 & 12.7 & 13.0 & 13.0 & 13.2 \\
\hline Social contributions & 13.9 & 14.2 & 14.4 & 14.3 & 14.0 & 13.7 & 13.6 \\
\hline Other taxes & 0.5 & 0.5 & 0.5 & 0.5 & 0.8 & 0.6 & 0.7 \\
\hline Nontax revenue & 4.7 & 5.2 & 5.1 & 6.9 & 4.7 & 5.1 & 4.8 \\
\hline Expenditure & 49.0 & 49.1 & 49.8 & 51.1 & 49.2 & 51.6 & 48.4 \\
\hline Primary expenditure & 42.4 & 42.6 & 44.1 & 45.8 & 44.5 & 47.5 & 44.4 \\
\hline Current expenditure & 39.3 & 40.2 & 41.6 & 42.7 & 42.2 & 42.4 & 41.9 \\
\hline Wages & 11.5 & 11.7 & 12.2 & 12.3 & 12.0 & 12.0 & 11.8 \\
\hline Operations and maintenance & 3.2 & 3.3 & 3.8 & 3.7 & 3.7 & 3.6 & 3.6 \\
\hline Social transfers & 21.3 & 21.8 & 22.3 & 23.0 & 23.0 & 22.8 & 22.4 \\
\hline Old age & 8.3 & 8.4 & 8.6 & 8.7 & 8.6 & 8.5 & 8.4 \\
\hline Health & 5.6 & 5.8 & 5.7 & 6.1 & 6.2 & 6.3 & 6.1 \\
\hline Unemployment & 1.7 & 1.8 & 2.0 & 2.1 & 2.1 & 2.0 & 1.9 \\
\hline Other social transfer & 5.7 & 5.8 & 6.0 & 6.1 & 6.1 & 6.0 & 6.0 \\
\hline Subsidies to enterprises & 1.3 & 1.3 & 1.3 & 1.4 & 1.2 & 1.6 & 1.7 \\
\hline Other transfers & 2.0 & 2.0 & 2.1 & 2.3 & 2.4 & 2.4 & 2.4 \\
\hline Capital expenditure & 3.1 & 2.4 & 2.5 & 3.1 & 2.2 & 5.1 & 2.5 \\
\hline Interest & 6.6 & 6.5 & 5.7 & 5.3 & 4.7 & 4.2 & 4.0 \\
\hline Overall balance & 0.1 & 0.6 & 0.0 & 0.0 & 0.0 & -2.3 & 0.4 \\
\hline Primary balance & 6.7 & 7.0 & 5.7 & 5.3 & 4.7 & 1.9 & 4.3 \\
\hline \multicolumn{8}{|l|}{ Memorandum items: } \\
\hline Structural balance & -0.5 & -0.4 & -0.2 & -1.0 & -0.6 & 0.4 & -0.1 \\
\hline Central government balance & 0.1 & -0.1 & 0.2 & 0.0 & -0.2 & -0.3 & -0.6 \\
\hline Gross public debt (Maastricht definition) & 107.7 & 106.5 & 103.5 & 98.7 & 94.4 & 92.2 & 88.1 \\
\hline
\end{tabular}

Source: Data provided by the Belgian authorities.

$1 /$ Includes the effect of the restructuring of the national railway company in 2005 as per Eurostat. According to the authorities, the government balance should be 0.1 percent of GDP in 2005 and the public debt 91.5 percent of GDP. 
Table 3. Belgium: Fiscal Scenarios, 2004-13

(In percent of GDP, unadjusted for working days; unless otherwise indicated)

\begin{tabular}{|c|c|c|c|c|c|c|c|c|c|c|}
\hline & \multirow[b]{2}{*}{2004} & \multirow[b]{2}{*}{2005} & \multirow[b]{2}{*}{2006} & \multirow{2}{*}{$\begin{array}{r}\text { Est. } \\
2007\end{array}$} & \multicolumn{6}{|c|}{ Projection } \\
\hline & & & & & 2008 & 2009 & 2010 & 2011 & 2012 & 2013 \\
\hline \multicolumn{11}{|l|}{ Current policies (A) } \\
\hline Revenue & 49.2 & 49.4 & 48.7 & 48.5 & 48.2 & 48.1 & 48.1 & 48.0 & 48.0 & 47.9 \\
\hline Expenditure & 49.2 & 51.6 & 48.4 & 48.7 & 48.7 & 48.7 & 48.5 & 48.4 & 48.3 & 48.2 \\
\hline Primary expenditure & 44.5 & 47.5 & 44.4 & 44.8 & 45.0 & 45.1 & 45.1 & 45.1 & 45.0 & 45.0 \\
\hline Interest payments & 4.7 & 4.2 & 4.0 & 3.8 & 3.7 & 3.6 & 3.5 & 3.4 & 3.3 & 3.2 \\
\hline Balance 1/ & 0.0 & -2.3 & 0.4 & -0.1 & -0.5 & -0.5 & -0.5 & -0.4 & -0.3 & -0.3 \\
\hline Structural balance 2/ & -0.6 & 0.4 & -0.1 & -0.1 & -0.2 & -0.2 & -0.2 & -0.2 & -0.1 & -0.1 \\
\hline Change in structural balance & 0.5 & 0.9 & -0.5 & 0.1 & -0.1 & 0.0 & 0.0 & 0.0 & 0.0 & 0.0 \\
\hline Primary balance & 4.7 & 1.9 & 4.3 & 3.7 & 3.2 & 3.0 & 3.0 & 3.0 & 2.9 & 2.9 \\
\hline Structural primary balance 2/ & 4.2 & 4.5 & 3.8 & 3.8 & 3.5 & 3.3 & 3.3 & 3.2 & 3.1 & 3.0 \\
\hline Debt $1 /$ & 94.4 & 92.2 & 88.1 & 85.1 & 82.3 & 79.8 & 77.3 & 74.9 & 72.6 & 70.4 \\
\hline \multicolumn{11}{|l|}{ Memorandum items (in percent): } \\
\hline Real primary expenditure growth 2/ & -0.2 & 8.9 & -3.7 & 3.7 & 2.0 & 2.0 & 2.0 & 2.0 & 2.0 & 2.0 \\
\hline Output gap & 0.0 & -0.2 & 0.2 & 0.4 & -0.2 & -0.4 & -0.3 & -0.2 & -0.1 & 0.0 \\
\hline GDP growth & 2.8 & 2.0 & 2.9 & 2.7 & 1.6 & 1.8 & 2.0 & 2.0 & 2.0 & 2.0 \\
\hline \multicolumn{11}{|l|}{ Staff-recommended scenario (B) } \\
\hline Revenue & 49.2 & 49.4 & 48.7 & 48.5 & 48.2 & 48.1 & 48.1 & 48.0 & 48.0 & 47.9 \\
\hline Expenditure & 49.2 & 51.6 & 48.4 & 48.7 & 48.1 & 47.6 & 47.1 & 46.8 & 46.4 & 46.1 \\
\hline Primary expenditure & 44.5 & 47.5 & 44.4 & 44.8 & 44.4 & 44.1 & 43.8 & 43.5 & 43.3 & 43.2 \\
\hline Interest payments & 4.7 & 4.2 & 4.0 & 3.8 & 3.7 & 3.5 & 3.4 & 3.2 & 3.1 & 2.9 \\
\hline Balance 1/ & 0.0 & -2.3 & 0.4 & -0.1 & 0.1 & 0.5 & 0.9 & 1.3 & 1.6 & 1.9 \\
\hline Structural balance 2/ & -0.6 & 0.4 & -0.1 & -0.1 & 0.4 & 0.8 & 1.2 & 1.5 & 1.8 & 2.0 \\
\hline Change in structural balance & 0.5 & 0.9 & -0.5 & 0.1 & 0.4 & 0.4 & 0.4 & 0.3 & 0.3 & 0.2 \\
\hline Primary balance & 4.7 & 1.9 & 4.3 & 3.7 & 3.8 & 4.1 & 4.3 & 4.5 & 4.6 & 4.7 \\
\hline Structural primary balance 2/ & 4.2 & 4.5 & 3.8 & 3.8 & 4.1 & 4.4 & 4.6 & 4.7 & 4.8 & 4.9 \\
\hline Debt $1 /$ & 94.4 & 92.2 & 88.1 & 85.1 & 81.7 & 78.2 & 74.3 & 70.4 & 66.4 & 62.3 \\
\hline \multicolumn{11}{|l|}{ Memorandum items (in percent): } \\
\hline Real primary expenditure growth 2/ & -0.2 & 8.9 & -3.7 & 3.7 & 0.6 & 0.9 & 1.2 & 1.5 & 1.5 & 1.6 \\
\hline Output gap & 0.0 & -0.2 & 0.2 & 0.4 & -0.2 & -0.5 & -0.4 & -0.3 & -0.2 & -0.1 \\
\hline GDP growth & 2.8 & 2.0 & 2.9 & 2.7 & 1.6 & 1.7 & 1.9 & 1.9 & 2.0 & 2.0 \\
\hline
\end{tabular}

Sources: Data provided by the authorities; and IMF staff projections.

1 / Includes the effect of the restructuring of the national railway company in 2005 as presented by Eurostat. According to the authorities, the government balance should be 0.1 percent of GDP in 2005 and the public debt 91.5 percent of GDP.

2/ Excludes one-off measures including the restructuring of the national railway company in 2005. 
Table 4. Belgium: Financial Soundness Indicators of the Non-Banking Sectors, 2001-07 (In percent)

\begin{tabular}{|c|c|c|c|c|c|c|c|c|}
\hline & & 2001 & 2002 & 2003 & 2004 & 2005 & 2006 & 2007 \\
\hline \multicolumn{9}{|c|}{ Insurance sector $1 /$} \\
\hline \multicolumn{2}{|c|}{ Coverage ratio $2 /$} & 276.0 & 254.1 & 248.4 & 250.7 & 258.8 & 252.6 & 256.7 \\
\hline \multicolumn{2}{|c|}{ Profitability (return on equity) $3 /$} & 12.1 & -10.4 & 7.3 & 18.0 & 23.3 & 20.8 & 30.1 \\
\hline \multirow[t]{2}{*}{ Life } & Premiums 4/ & 13.1 & 14.4 & 17.6 & 20.0 & 25.2 & 20.4 & 23.1 \\
\hline & Technical result/premiums $3 /$ & 6.1 & -1.7 & 2.7 & 4.0 & 4.7 & 4.9 & 6.8 \\
\hline \multirow[t]{3}{*}{ Non-life } & Premiums 4/ & 7.8 & 8.5 & 9.0 & 9.6 & 8.9 & 9.3 & 9.8 \\
\hline & Combined ratio $3 /$ & 117.5 & 111.6 & 102.1 & 99.6 & 104.3 & 101.7 & 100.4 \\
\hline & Technical result/premiums 3/ & 0.0 & -3.4 & 8.8 & 12.8 & 12.0 & 12.7 & 16.7 \\
\hline \multicolumn{9}{|c|}{ Corporate sector $5 /$} \\
\hline \multicolumn{2}{|c|}{ Total debt (percent of equity) } & 83.0 & 79.5 & 78.2 & 70.6 & 65.6 & 60.5 & $\ldots$ \\
\hline \multicolumn{2}{|c|}{ Profitability (return on equity) } & 9.8 & 11.7 & 12.9 & 10.4 & 15.8 & 14.8 & \\
\hline \multicolumn{2}{|c|}{ Debt service coverage ratio } & 113.6 & 176.7 & 195.6 & 182.8 & 285.0 & 236.4 & ... \\
\hline \multicolumn{9}{|c|}{ Household sector } \\
\hline \multicolumn{2}{|c|}{ Debt (in percent of GDP) 6/ } & 41.3 & 41.4 & 42.3 & 43.1 & 41.1 & 46.2 & 48.8 \\
\hline \multicolumn{2}{|c|}{ Interest burden (in percent of disposable income) 7/ } & 2.5 & 1.8 & 1.5 & 1.2 & 1.6 & 2.0 & 2.0 \\
\hline \multicolumn{2}{|c|}{ Financial savings ratio (in percent of GDP) 6/ } & 7.5 & 5.0 & 4.0 & 4.8 & 1.5 & 2.4 & 6.2 \\
\hline \multicolumn{2}{|c|}{ Savings rate $7 /$} & 16.6 & 15.9 & 14.8 & 13.5 & 12.3 & 12.6 & 12.8 \\
\hline \multicolumn{9}{|c|}{$\begin{array}{l}\text { Real estate sector } 8 / \\
\text { House price inflation }\end{array}$} \\
\hline & Houses & 6.4 & 8.2 & 6.6 & 10.3 & 18.1 & 11.2 & 7.1 \\
\hline & Apartments & 4.4 & 8.3 & 8.9 & 14.6 & 9.4 & 10.1 & 6.3 \\
\hline Mortgag & e loans as percent of total loans & 20.5 & 22.3 & 27.6 & 27.4 & 26.2 & 34.0 & 30.5 \\
\hline $\mathrm{o} / \mathrm{h}$ & Domestic households & 13.3 & 14.2 & 15.6 & 15.5 & 14.5 & 17.5 & 16.7 \\
\hline Variable & rate mortgages (in percent of new loans) & 6.2 & 12.3 & 25.9 & 53.3 & 36.3 & 7.4 & 1.2 \\
\hline
\end{tabular}

Sources: CBFA, NBB, Stadim, UPC.

$1 /$ Unconsolidated data.

2/ Provisional figure for end-September 2007.

3/ Provisional 2007 figure for first 9 months annualised.

4/ Provisional figure for full year 2007, based on projection by Assuralia.

5/ Data for 2006 based on a sample of available annual accounts in the Central Balance Sheet Register.

6/ 2007 figure for end-June 2007.

7/ Projection for full year 2007.

8/ 2007 data for first half of 2007. 
Table 5. Belgium: Financial Soundness Indicators of the Banking Sector, 2002-07 1/

\begin{tabular}{|c|c|c|c|c|c|c|}
\hline \multirow[b]{3}{*}{ Earnings and profitability } & 2002 & 2003 & 2004 & 2005 & 2006 & $20072 /$ \\
\hline & \multicolumn{4}{|c|}{ Belgian GAAP } & \multicolumn{2}{|c|}{ IFRS } \\
\hline & & & & & & \\
\hline Return on assets & 0.4 & 0.4 & 0.5 & 0.5 & 0.7 & 0.7 \\
\hline Return on equity & 11.8 & 13.6 & 15.8 & 18.5 & 22.4 & 23.4 \\
\hline Net interest income to total income & 55.1 & 56.4 & 56.3 & 53.5 & 47.9 & 48.4 \\
\hline Interest margin & 1.5 & 1.4 & 1.3 & 1.2 & 1.0 & 1.0 \\
\hline Average yield on assets & 4.9 & 4.0 & 3.9 & 4.1 & 4.6 & 5.3 \\
\hline Average cost of funding & 3.4 & 2.6 & 2.6 & 2.9 & 3.6 & 4.3 \\
\hline Noninterest expenses to gross income & 44.9 & 43.6 & 43.7 & 46.5 & 52.1 & 51.6 \\
\hline $\mathrm{o} / \mathrm{w}$ Net fee and commission income & 24.6 & 24.4 & 25.5 & 25.9 & 25.1 & 27.9 \\
\hline (Un)realised capital gains booked in P\&L & 9.9 & 10.1 & 8.9 & 8.2 & 14.6 & 18.1 \\
\hline Cost/income ratio & 74.7 & 73.9 & 72.0 & 72.6 & 55.7 & 58.8 \\
\hline Personnel expenses to noninterest expenses & 44.3 & 45.5 & 44.7 & 42.8 & 54.7 & 53.4 \\
\hline \multicolumn{7}{|l|}{ Structure assets } \\
\hline Total assets (in percent of GDP) & 383.1 & 376.2 & 395.4 & 453.5 & 448.5 & 473.9 \\
\hline \multicolumn{7}{|l|}{$\mathrm{o} / \mathrm{w}$ (in percent of total assets) } \\
\hline Loans to credit institutions $3 /$ & 21.0 & 20.0 & 18.6 & 20.3 & 20.1 & 19.6 \\
\hline Debt securities 3/ & 27.1 & 27.4 & 25.5 & 23.4 & 22.5 & 19.5 \\
\hline Equity instruments 3/ & 1.3 & 1.7 & 2.7 & 3.5 & 3.6 & 4.0 \\
\hline Derivatives $3 /$ & 0.0 & 0.0 & 0.0 & 0.0 & 4.5 & 5.4 \\
\hline Loans to customers $3 /$ & 41.1 & 41.5 & 42.2 & 43.2 & 41.6 & 42.5 \\
\hline \multirow{3}{*}{$\begin{array}{l}\text { o/w Belgian residents (in percent of loans) } \\
\text { Other EMU residents (in percent of loans) } \\
\text { Rest of the World (in percent of loans) }\end{array}$} & 52.1 & 52.3 & 48.5 & 41.6 & 43.0 & 43.0 \\
\hline & 21.7 & 22.5 & 22.7 & 25.5 & 29.0 & 30.0 \\
\hline & 26.2 & 25.2 & 28.8 & 32.9 & 28.0 & 27.0 \\
\hline \multirow{2}{*}{$\begin{array}{l}\text { o/w Mortgage loans (in percent of loans) } \\
\text { Consumer loans (in percent of loans) }\end{array}$} & 93.6 & 117.4 & 132.0 & 154.7 & 189.7 & 193.0 \\
\hline & 14.3 & 13.5 & 12.7 & 13.7 & 15.4 & 16.0 \\
\hline o/w Term loans (in percent of loans) & 57.5 & 53.7 & 53.5 & 54.8 & 46.1 & 37.7 \\
\hline o/w Reverse repo operations (in percent of loans) & $\ldots$ & $\ldots$ & $\ldots$ & $\ldots$ & 41.0 & 32.6 \\
\hline \multicolumn{7}{|l|}{ Funding and Liquidity $\mathbf{3}$ (in percent of total assets) } \\
\hline Debts to credit institutions & 24.9 & 24.9 & 24.6 & 30.1 & 29.2 & 26.7 \\
\hline Bank bonds and other debt securities & 12.6 & 11.2 & 10.0 & 8.7 & 11.2 & 11.5 \\
\hline Customer deposits & 39.7 & 40.3 & 39.9 & 36.7 & 39.1 & 38.5 \\
\hline o/w Sight deposits 3/ & 13.3 & 13.7 & 13.4 & 13.5 & 11.1 & 12.1 \\
\hline Saving deposits $3 /$ & 11.1 & 12.9 & 13.2 & 11.6 & 10.2 & 8.6 \\
\hline Term deposits $3 /$ & 14.3 & 12.5 & 12.1 & 10.6 & 10.6 & 11.3 \\
\hline o/w Retail deposits & $\ldots$ & $\ldots$ & $\ldots$ & $\ldots$ & 20.4 & 18.0 \\
\hline o/w Repo's & $\ldots$ & $\ldots$ & $\ldots$ & $\ldots$ & 13.5 & 11.2 \\
\hline Liquid assets 4/ & 33.3 & 33.2 & 32.7 & 31.1 & 18.6 & 16.0 \\
\hline \multicolumn{7}{|l|}{ Asset quality } \\
\hline \multicolumn{7}{|l|}{ Sectoral distribution of loans } \\
\hline Credit institutions & $\ldots$ & $\ldots$ & $\ldots$ & $\ldots$ & 20.1 & 19.6 \\
\hline Corporate & $\ldots$ & $\ldots$ & $\ldots$ & $\ldots$ & 18.3 & 19.7 \\
\hline Retail & $\ldots$ & $\ldots$ & $\ldots$ & $\ldots$ & 18.3 & 16.7 \\
\hline Central governments & $\ldots$ & $\ldots$ & $\ldots$ & $\ldots$ & 0.8 & 1.0 \\
\hline Non-credit institutions & & $\ldots$ & $\ldots$ & & 4.1 & 5.2 \\
\hline Non-performing loans (in percent of gross loans) 5/ & 3.0 & 2.6 & 2.3 & 2.0 & 1.7 & 1.6 \\
\hline Provisions + writeoffs (in percent of NPL) $5 /$ & 51.8 & 52.8 & 54.2 & 51.6 & 50.8 & 45.0 \\
\hline \multicolumn{7}{|l|}{ Capital adequacy } \\
\hline Regulatory capital to risk-weighted assets & 13.1 & 12.8 & 13.0 & 11.5 & 11.9 & 11.9 \\
\hline Regulatory Tier I capital to risk-weighted assets & 8.6 & 8.8 & 9.4 & 8.5 & 8.7 & 8.5 \\
\hline Capital to assets & 3.0 & 3.1 & 3.1 & 2.7 & 3.3 & 3.2 \\
\hline NPL net of provisions as percent of Tier I capital 5/ & 15.2 & 15.7 & 12.8 & 13.8 & 10.9 & 11.6 \\
\hline Large exposures as percent of Tier I capital 5/ & 61.0 & 46.0 & 40.0 & 42.5 & 36.2 & 16.8 \\
\hline Net open position in foreign exchange to capital & 8.5 & 7.0 & 5.3 & 5.8 & 6.4 & 4.1 \\
\hline
\end{tabular}

Sources: CBFA and NBB.

1/ Consolidated data. Since 2006, the data are based on the IAS/IFRS reporting Scheme.

2/ Data for end-September 2007 or the first 9 months of 2007. The flow data are annualised.

3/ Deposits booked at amortised cost only.

4/ As of 2006, liquid assets include cash and debt instruments issued by central government and financial institutions.

$5 /$ Unconsolidated data. 
Table 6. Belgium: Indicators of External and Financial Vulnerability, 2001-07

\begin{tabular}{|c|c|c|c|c|c|c|c|}
\hline & 2001 & 2002 & 2003 & 2004 & 2005 & 2006 & 2007 \\
\hline \multicolumn{8}{|l|}{ External Indicators } \\
\hline Exports (annual percentage change, in U.S. dollars) 1/ & -0.4 & 6.3 & 20.6 & 19.4 & 7.2 & 6.6 & 19.5 \\
\hline Imports (annual percentage change, in U.S. dollars) $1 /$ & -0.6 & 4.2 & 21.2 & 20.2 & 8.4 & 7.2 & 19.0 \\
\hline Terms of trade (annual percentage change) $1 /$ & -1.0 & 1.8 & -0.4 & -1.3 & -1.0 & -1.2 & 0.9 \\
\hline Current account balance (percent of GDP) 1/ & 3.4 & 4.6 & 4.1 & 3.5 & 2.6 & 2.7 & 3.3 \\
\hline Inward portfolio investment (percent of GDP) 2/ & 63.5 & 8.1 & 2.5 & 1.5 & -0.5 & 4.4 & $\ldots$ \\
\hline Inward foreign direct investment (percent of GDP) 2/ & 23.7 & 6.5 & 10.8 & 12.1 & 9.2 & 15.7 & $\ldots$ \\
\hline Official reserves (in billions of U.S. dollars, end-of-period) 3 & 11.3 & 11.9 & 11.0 & 10.4 & 8.2 & 8.8 & 10.4 \\
\hline Official reserves in months of imports & 0.7 & 0.7 & 0.6 & 0.4 & 0.3 & 0.3 & 0.3 \\
\hline Exchange rate per U.S. dollar (period average) 4/ 4/ & 1.117 & 1.059 & 0.884 & 0.804 & 0.803 & 0.796 & 0.730 \\
\hline \multicolumn{8}{|l|}{ Market indicators } \\
\hline \multicolumn{8}{|l|}{ Financial markets indicators 4 / } \\
\hline Public sector debt (Maastricht definition) 1/ & 106.5 & 103.5 & 98.7 & 94.4 & 92.2 & 88.1 & 84.5 \\
\hline 3-month T-bill yield (percent) & 4.2 & 3.2 & 2.2 & 2.0 & 2.1 & 3.4 & 3.8 \\
\hline 3-month T-bill yield (real, percent) & 1.7 & 1.5 & 0.6 & -0.3 & -0.4 & 1.0 & 2.0 \\
\hline Spread of 3-month T-bill over EURIBOR (percentage poil & 0.0 & -0.1 & -0.1 & -0.1 & -0.2 & -0.1 & 0.0 \\
\hline 10-year government bond yield (percent) & 5.1 & 5.0 & 4.2 & 4.3 & 3.4 & 3.8 & 4.4 \\
\hline 10-year government bond yield (real, percent) & 2.7 & 3.4 & 2.7 & 2.5 & 0.9 & 1.5 & 2.6 \\
\hline Spread of 10-year government bond rate with Germany & & & & & & & \\
\hline (percentage points) & 0.3 & 0.2 & 0.1 & 0.1 & 0.2 & -0.1 & 0.0 \\
\hline Stock market index (period average) & 2,807 & 2,410 & 1,975 & 2,557 & 3,192 & 3,961 & 4,501 \\
\hline \multicolumn{8}{|c|}{ Credit markets indicators (end-of-period; percentage increase) 5/ } \\
\hline Bank Credit to the private sector & 6.0 & 1.2 & 1.8 & 12.6 & 22.4 & $\ldots$ & 12.7 \\
\hline Belgian residents & 2.0 & -0.3 & 2.2 & 4.4 & 5.0 & $\ldots$ & 12.7 \\
\hline Other EMU residents & 7.9 & -2.0 & 5.5 & 13.6 & 37.6 & $\ldots$ & 16.6 \\
\hline Rest of the World & 13.8 & 7.3 & -2.1 & 28.7 & 39.9 & $\ldots$ & 8.7 \\
\hline Mortgage loans & 13.3 & 11.4 & 27.7 & 26.6 & 43.5 & $\ldots$ & 14.7 \\
\hline Consumer loans & 7.6 & 4.1 & -3.9 & 5.9 & 32.1 & $\ldots$ & 17.1 \\
\hline \multicolumn{8}{|l|}{ Banking sector capital adequacy (in percent) } \\
\hline Regulatory capital to risk-weighted assets & 12.9 & 13.1 & 12.8 & 13 & 11.5 & 11.9 & 11.9 \\
\hline Regulatory Tier I capital to risk-weighted assets & 8.2 & 8.6 & 8.8 & 9.4 & 8.5 & 8.7 & 8.5 \\
\hline Capital to assets & 2.7 & 3 & 3.1 & 3.1 & 2.7 & 3.3 & 3.2 \\
\hline NPL net of provisions as percent of Tier I capital 6/ & 14.4 & 15.2 & 15.7 & 12.8 & 13.8 & 10.9 & 11.6 \\
\hline Large exposures as percent of Tier I capital $7 /$ & 67 & 61 & 46 & 40 & 42.5 & 36.2 & 16.8 \\
\hline Net open position in foreign exchange to capital $7 /$ & 6.8 & 8.5 & 7 & 5.3 & 5.8 & 6.4 & 4.1 \\
\hline
\end{tabular}

Sources: Data provided by the Belgian authorities; IMF, IFS; and IMF Research Department.

$1 /$ IMF staff projection.

2/ Data before 2002 cover the definition of the Belgium-Luxembourg Economic Union (BLEU).

3/ October 2007; reserves and foreign liabilities refer to the Belgian central bank, both before and after EMU.

4/ Latest data.

5/ Beginning 2006 data under IFRS while before data was under Belgium GAAP, hence data break in 2006.

$6 /$ Unconsolidated data.

7/ The 2007 figure refers to banks still applying Basel I. 


\section{APPENDIX I. BELGIUM: FUND RELATIONS}

(As of January 31, 2008)

Mission: Brussels, December 6-17, 2007 and January 23-28, 2008

Staff team: Messrs. Everaert (Head), Christou (first mission only), Luzio (second mission only), Ms. Yontcheva (all EUR), and Mr. De Broeck (FAD, first mission only).

Country interlocutors: The prime minister, the vice-prime minister for the budget, the governor of the National Bank of Belgium, the director of the Treasury, the chairman of the Finance, Banking and Insurance Commission, the Head of the Federal Planning Bureau, the chairman of the public borrowing section of the High Finance Council, and their staffs; staff of the federal ministry of finance, the health care administration, the regional ministries of the budget for Flanders, Brussels and Wallonia, respectively; representatives of labor unions, employer organizations, and the financial sector. Mr. Kiekens (Executive Director) or Mr. Rottier (Advisor to the Executive Director) attended the meetings.

Fund relations: The previous Article IV consultation took place on February 16, 2007. The associated Executive Board's assessment is available at http://www.imf.org/external/np/sec/pn/2007/pn0726.htm and the staff report at http:/www.imf.org/external/pubs/ft/scr/2007/cr0789.pdf. Belgium accepted the obligations under Article VIII and, apart from certain security restrictions, maintains an exchange system free of restrictions.

Data: Belgium subscribes to the Fund's Special Data Dissemination Standard, and comprehensive economic data are available on a timely basis (Appendix II).

I. Membership Status: Joined 12/27/45; Article VIII

II. General Resources Account:

Quota

Fund holdings of currency

Reserve position in Fund

III. SDR Department:

Net cumulative allocation

Holdings

[Designation plan]

\section{SDR Million}

$4,605.20$

$4,303.11$

302.130

SDR Million

485.25

387.00
Percent of Quota

100.00

93.44

6.56

IV. Outstanding Purchases and Loans: None 
V. Latest Financial Arrangements: None

VI. Projected Payments to Fund (SDR million; based on existing use of resources and present holdings of SDRs):

Principal

Charges/interest

Total

\begin{tabular}{lllll}
\multicolumn{5}{c}{ Forthcoming } \\
\hline $\mathbf{2 0 0 8}$ & $\mathbf{2 0 0 9}$ & $\mathbf{2 0 1 0}$ & $\mathbf{2 0 1 1}$ & $\mathbf{2 0 1 2}$ \\
$\frac{3.18}{3.18}$ & $\frac{3.06}{3.06}$ & $\frac{3.06}{3.06}$ & $\frac{3.06}{3.06}$ & $\frac{3.06}{3.06}$
\end{tabular}

\section{Article IV Consultations:}

Belgium is on the 12-month cycle; the last consultation was completed on February 16, 2007 (EBM/07/14).

\section{Exchange Rate Arrangements}

- $\quad$ Belgium's currency is the euro, which floats freely and independently against other currencies.

- $\quad$ Belgium maintains an exchange system free of restrictions on payments and transfers for current international transactions, except for restrictions maintained solely for security reasons. These measures are established by European Union regulations and have been notified to the Fund pursuant to Executive Board Decision No. 144-(52/51) (see EBD/90/251 (8/17/90), EBD/94/187 (11/29/94), EBD/92/139 (7/7/92) and $\operatorname{EBD} / 06 / 133(11 / 6 / 2006))$.

\section{FSAP Participation:}

\section{FSAP Assessment}

IMF Country Report No. 06/75

Summary: The report concluded that Belgium's financial system is resilient and benefits from a number of Belgium-specific features that help stability. These include a traditionally cautious attitude toward risk by banks, large holdings of government securities, extremely low holdings of equity by banks, a stable source of funding benefiting from generous tax incentives, a high standard of banking supervision, and a stable macroeconomic policy framework. Overall, supervision showed a high degree of compliance with international standards. Near-term vulnerability appears low, reflecting the soundness of the dominant banking system, the generally benign financial environment, the strong financial condition of the corporate sector, and the relatively healthy financial position of the household sector. Financial institutions were found to withstand an adverse macroeconomic stress well, helped in part by the beneficial diversification in the bancassurance model. 
Notwithstanding the strengths of the Belgian financial sector, a number of issues emerged from the FSAP. The heavy exposure abroad, the open nature of the economy, and the importance of the Euroclear Group globally, made the domestic financial system potentially vulnerable to global economic developments and financial contagion. Risks remained and may increase with a downturn in the business cycle, increased cross-border operations, and deeper links with the global money centers. In line with the 2005 FSAP recommendations, the supervisory framework has been strengthened. The Banking, Finance, and Insurance Commission's (CBFA) management committee has been streamlined and synergies between the CBFA and the National Bank of Belgium (NBB) have been further developed. Regular stress tests have helped promote a systematic dialogue between supervisory authorities and market participants, while detailed procedures for financial crisis management have been tested. Prudential supervision of the insurance sector has been upgraded and regulation of the pension funds sector reinforced. 


\section{APPENDIX II. BELGIUM: STATISTICAL ISSUES}

Belgium's economic and financial statistics are adequate for surveillance purposes. The National Bank of Belgium (NBB) regularly publishes a full range of economic and financial data and provides calendar dates of main statistical releases. On-line access to these comprehensive databases is facilitated by the NBB's data search engine, Belgostat. Belgium is a SDDS subscriber. Statistics for International Financial Statistics on banking institutions and monetary aggregates are prepared on a monthly basis and are timely.

Belgium adopted the European System of Integrated Economic Accounts 1995 (ESA95) in 1999. Revisions of national accounts started in November 2005 to comply with EUROSTAT requirements and prepare for the adoption of chain-linked national accounts statistics. Unlike in other countries, the NBB is responsible for compiling national accounts statistics. Quarterly accounts are published within a lag of three months. Both annual and quarterly accounts data are of good quality, with shortcomings mainly related to export and import deflators, which are based on unit values, rather than prices collected directly from exporters and importers.

General government revenue, expenditure, and balance on an accrual basis (ESA95) are published annually. The NBB publishes monthly data on central government operations and quarterly data on general government operations since April 2007.

The overall quality and availability of financial indicators are good. The authorities are providing quarterly updates of financial sector indicators (FSIs) in a timely manner.

Key publicly accessible websites for macroeconomic data and analysis are:

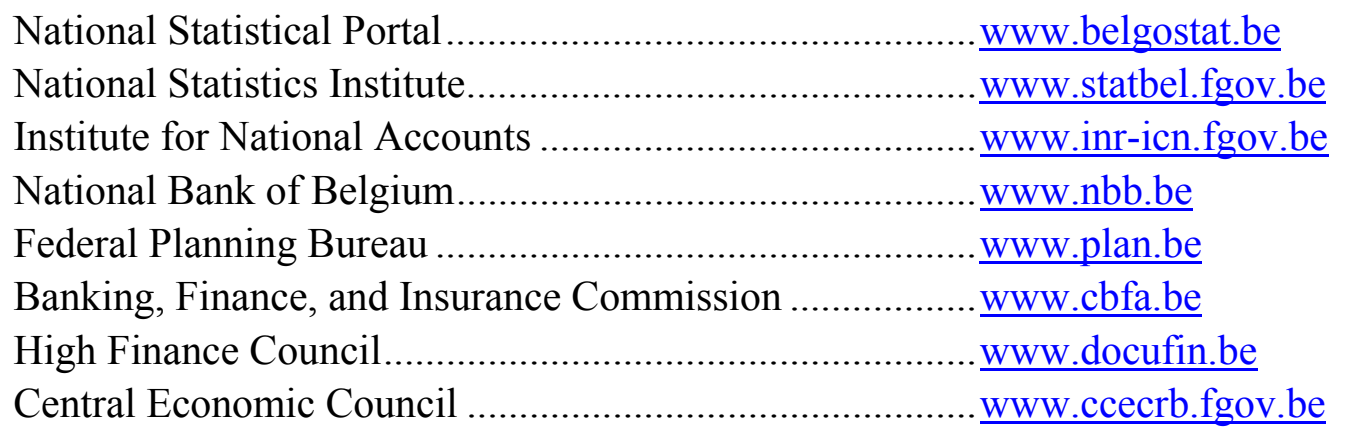




\section{BELGIUM: TABLE OF COMMON INDICATORS REQUIRED FOR SURVEILLANCE}

(As of February 14, 2008)

\begin{tabular}{|l|c|c|c|c|c|}
\hline & $\begin{array}{c}\text { Date of } \\
\text { Latest } \\
\text { Observation }\end{array}$ & $\begin{array}{c}\text { Date } \\
\text { Received }\end{array}$ & $\begin{array}{c}\text { Frequency } \\
\text { of } \\
\text { Data }^{6}\end{array}$ & $\begin{array}{c}\text { Frequency } \\
\text { of } \\
\text { Reporting }^{6}\end{array}$ & $\begin{array}{c}\text { Frequency } \\
\text { of } \\
\text { Publication }^{6}\end{array}$ \\
\hline Exchange Rates & $2 / 14 / 08$ & $2 / 14 / 08$ & $\mathrm{D}$ & $\mathrm{D}$ & $\mathrm{D}$ \\
\hline $\begin{array}{l}\text { International Reserve Assets and Reserve } \\
\text { Liabilities of the Monetary Authorities }\end{array}$ & $11 / 07$ & $1 / 14 / 08$ & $\mathrm{M}$ & $\mathrm{M}$ & $\mathrm{M}$ \\
\hline Reserve/Base Money & $12 / 07$ & $1 / 08$ & $\mathrm{M}$ & $\mathrm{M}$ & $\mathrm{M}$ \\
\hline Broad Money & $12 / 07$ & $1 / 08$ & $\mathrm{M}$ & $\mathrm{M}$ & $\mathrm{M}$ \\
\hline Central Bank Balance Sheet & $12 / 07$ & $1 / 08$ & $\mathrm{M}$ & $\mathrm{M}$ & $\mathrm{M}$ \\
\hline $\begin{array}{l}\text { Consolidated Balance Sheet of the Banking } \\
\text { System }\end{array}$ & $12 / 07$ & $1 / 08$ & $\mathrm{M}$ & $\mathrm{M}$ & $\mathrm{M}$ \\
\hline Interest Rates & & & & $\mathrm{D}$ \\
\hline Consumer Price Index & $2 / 14 / 08$ & $2 / 14 / 08$ & $\mathrm{D}$ & $\mathrm{D}$ & $\mathrm{D}$ \\
\hline $\begin{array}{l}\text { Revenue, Expenditure, Balance and } \\
\text { Composition of Financing } \\
\text { Government }\end{array}$ & $12 / 07$ & $1 / 08$ & $\mathrm{M}$ & $\mathrm{M}$ & $\mathrm{M}$ \\
\hline $\begin{array}{l}\text { Revenue, Expenditure, Balance, and } \\
\text { Composition of Financing } \\
\text { Government }\end{array}$ & 2006 & $6 / 30 / 07$ & $\mathrm{~A}$ & $\mathrm{~A}$ & $\mathrm{~A}$ \\
\hline $\begin{array}{l}\text { Stocks of Central Government and Central } \\
\text { Government-Guaranteed Debt }\end{array}$ & $12 / 07$ & $1 / 08$ & $\mathrm{M}$ & $\mathrm{M}$ & $\mathrm{M}$ \\
\hline External Current Account Balance & $\mathrm{Q} 32007$ & $12 / 07$ & $\mathrm{Q}$ & $\mathrm{Q}$ & $\mathrm{Q}$ \\
\hline Exports and Imports of Goods and Services & $\mathrm{Q} 32007$ & $12 / 07$ & $\mathrm{Q}$ & $\mathrm{Q}$ & $\mathrm{Q}$ \\
\hline GDP/GNP & $\mathrm{Q} 32007$ & $12 / 07$ & $\mathrm{Q}$ & $\mathrm{Q}$ & $\mathrm{Q}$ \\
\hline Gross External Debt & $\mathrm{Q} 32007$ & $12 / 07$ & $\mathrm{Q}$ & $\mathrm{Q}$ & $\mathrm{Q}$ \\
\hline
\end{tabular}

${ }^{1}$ Includes reserve assets pledged or otherwise encumbered as well as net derivative positions.

${ }^{2}$ Both market-based and officially-determined, including discount rates, money market rates, rates on treasury bills, notes and bonds.

${ }^{3}$ Foreign, domestic bank, and domestic nonbank financing.

${ }^{4}$ The general government consists of the central government (budgetary funds, extra budgetary funds, and social security funds) and state and local governments.

${ }^{5}$ Including currency and maturity composition.

${ }^{6}$ Daily (D), weekly (W), monthly (M), quarterly (Q), annually (A), irregular (I); and not available (NA). 


\title{
INTERNATIONAL MONETARY FUND
}

\section{BELGIUM}

\section{Staff Report for the 2007 Article IV Consultation Supplementary Information}

\author{
Prepared by the European Department \\ (In consultation with the Policy Development and Review Department) \\ Approved by Alessandro Leipold and Michael Hadjimichael
}

March 19, 2008

This supplement to the staff report for the 2007 Article IV consultation with Belgium provides an update on the staff's revised economic outlook, recent developments in financial markets, and the 2008 budget proposal. A fiscal ROSC is being issued separately in the context of this Article IV consultation. The information does not alter the thrust of the staff appraisal.

\section{Summary}

Growth is forecast to dip to 1.4 percent in 2008, somewhat lower than anticipated in the staff report due to a further weakening of the global environment. Headline inflation has risen more than expected in January, given higher oil and food prices. The financial system has absorbed further write-downs linked to the ongoing financial turmoil. The government has reached agreement on balancing the 2008 general government budget.

\section{Output and inflation}

\section{Staff projects a deceleration of GDP growth to 1.4 percent in 2008, from}

1.6 percent growth in the Staff Report (Table 1). The revision is driven by slower growth in the U.S. and Europe and reflects broadly evenhanded reductions in growth among Belgium's main economic partners. While consumer and business confidence remained strong in January, encouraged by continued credit supply, inflation is higher and the impact of the global financial market turmoil is expected to be larger than envisaged earlier. In addition, significant downside risks remain, related to the international environment and financial turmoil. 


\section{Financial sector}

2. The financial sector disclosed additional subprime-related losses. Recent volatility in equity prices as well as a widening of credit default spreads indicates continuing market concerns about asset valuations and their implications for banks' earnings and capital. Credit default swap spreads have increased sharply for all Belgian banks, in line with those for banks in other euro area countries, and perhaps also related to exposure to emerging Europe whose vulnerabilities have risen. Fortis, Belgium's largest bank, reported a 45 percent decline in Q4 profits and has further shored up its capital. While Moody's reaffirmed the AAA rating of Dexia's U.S bond insurance unit, FSA, Dexia's CDS spreads continued to increase. If they remain high or widen further, additional accounting impacts on Dexia's first quarter results may be expected.

\section{8 budget}

3. The authorities agreed on balancing the 2008 general government budget. The federal budget frees up $€ 340$ million ( 0.1 percentage point of GDP) for well-targeted initiatives to support purchasing power, notably through an increase in small pensions and a tax reduction for low-income workers. At the same time, a special tax for power companies, the sale of vacant government-owned buildings, and increased efforts to reduce tax fraud are expected to boost revenues. Regional authorities have agreed to aim for a surplus of 0.2 percent of GDP in 2008. Discussions on the economic program for the follow up fullfledged federal government - which is to take office before end-March — continue and will be reflected in the new budget. Achieving a balanced budget would imply essentially no structural adjustment on the basis of the authorities' macroeconomic assumptions. The budget agreement does not materially alter the staff's appraisal, though the recourse to oneoff measures (albeit on an admittedly very limited scale, slightly less than 0.1 percent of GDP) reduces somewhat the quality of the underlying adjustment (Text Table 1 and Table 2).

Text Table 1. Belgium: General Government Fiscal Indicators, 2003-2009 (In percent of GDP, unless otherwise indicated)

\begin{tabular}{lrrrrrrr}
\hline & & & & \multicolumn{2}{c}{ Est. } & \multicolumn{2}{c}{ Proj. 1/ } \\
\cline { 5 - 8 } & 2003 & 2004 & 2005 & 2006 & 2007 & 2008 & 2009 \\
\hline General government balance 2/ & 0.0 & 0.0 & -2.3 & 0.4 & -0.1 & -0.3 & -0.7 \\
$\quad$ Nonstructural measures & 1.2 & 0.8 & -2.0 & 0.7 & -0.1 & 0.1 & 0.0 \\
Structural balance & -1.0 & -0.6 & 0.4 & -0.1 & -0.1 & 0.0 & 0.0 \\
$\quad$ Interest charges & 5.3 & 4.7 & 4.2 & 4.0 & 3.8 & 3.7 & 3.6 \\
Structural primary balance & 4.3 & 4.2 & 4.5 & 3.8 & 3.7 & 3.6 & 3.6 \\
Change in structural balance & -0.8 & 0.5 & 0.9 & -0.5 & 0.0 & 0.0 & 0.0 \\
Public debt 2/ & 98.7 & 94.4 & 92.2 & 88.1 & 85.1 & 82.0 & 80.3 \\
Memorandum items: & & & & & & & \\
$\quad$ Real primary spending growth (in percent) 2/ & 4.9 & -0.2 & 8.9 & -3.7 & 3.7 & 1.7 & 1.8 \\
$\quad$ Real GDP growth & 1.0 & 2.8 & 2.0 & 2.9 & 2.7 & 1.4 & 1.2 \\
\hline
\end{tabular}

Sources: National Bank of Belgium; and IMF staff.

$1 /$ Based on unchanged policy assumption.

2/ Assumes Eurostat's treatment of the national railway company debt transfer in 2005. 


\section{Fiscal ROSC}

4. Belgium broadly meets, and in several areas exceeds, the requirements of the fiscal transparency code. Budget formulation is supported by medium-term macroeconomic forecasts and clearly formulated medium-term fiscal policy goals. On the expenditure side, there is room to clarify objectives and targets to help gear decision-making toward the medium term. More information could be included in the budget on tax expenditures and fiscal risks, while institutional arrangements for fiscal policy coordination could be strengthened. A detailed assessment is presented in the accompanying Report on The Observance of Standards and Codes: Fiscal Transparency Module. 
Table 1. Belgium: Main Economic Indicators, 2003-09

(Percentage change from previous year; unless otherwise indicated)

\begin{tabular}{|c|c|c|c|c|c|c|c|}
\hline & \multirow[b]{2}{*}{2003} & \multirow[b]{2}{*}{2004} & \multirow[b]{2}{*}{2005} & \multirow[b]{2}{*}{2006} & \multirow{2}{*}{$\begin{array}{l}\text { Est. } \\
2007\end{array}$} & \multicolumn{2}{|c|}{ Proj. } \\
\hline & & & & & & 2008 & 2009 \\
\hline \multicolumn{8}{|l|}{ Demand and output (in real terms) } \\
\hline GDP & 1.0 & 2.8 & 2.0 & 2.9 & 2.7 & 1.4 & 1.2 \\
\hline Private consumption & 0.7 & 1.4 & 1.4 & 2.1 & 2.5 & 1.6 & 1.2 \\
\hline Public consumption & 2.1 & 1.8 & -0.2 & 0.0 & 1.8 & 2.3 & 2.0 \\
\hline Gross fixed investment & -0.3 & 7.5 & 6.7 & 4.2 & 4.9 & 1.4 & 1.1 \\
\hline Of which: enterprise investment & -1.8 & 7.4 & 4.6 & 3.9 & 5.1 & 1.9 & 1.5 \\
\hline Stockbuilding $1 /$ & 0.0 & 0.2 & 0.2 & 0.8 & 0.1 & 0.1 & -0.1 \\
\hline Exports of goods and nonfactor services & 2.9 & 6.3 & 4.1 & 2.6 & 4.6 & 4.3 & 3.7 \\
\hline Imports of goods and nonfactor services & 2.8 & 6.5 & 4.9 & 2.5 & 5.0 & 5.0 & 3.7 \\
\hline Foreign balance $1 /$ & 0.2 & 0.1 & -0.5 & 0.2 & -0.1 & -0.5 & 0.1 \\
\hline Output gap (in percent of potential GDP) & -0.9 & 0.0 & -0.2 & 0.2 & 0.5 & -0.4 & -1.2 \\
\hline \multicolumn{8}{|l|}{ Labor market } \\
\hline Labor force (national definition) & 1.1 & 1.5 & 1.5 & 1.0 & 0.5 & 0.6 & 0.7 \\
\hline Employment (national definition) & 0.1 & 0.7 & 1.2 & 1.3 & 1.6 & 0.4 & -0.2 \\
\hline EU harmonized unemployment rate 2/ & 8.2 & 8.4 & 8.4 & 8.2 & 7.5 & 7.6 & 8.3 \\
\hline NAIRU 2/ & 7.9 & 7.9 & 7.8 & 7.7 & 7.6 & 7.5 & 7.5 \\
\hline \multicolumn{8}{|l|}{ Prices, wages, and incomes } \\
\hline GDP deflator & 1.6 & 2.4 & 2.4 & 2.0 & 1.7 & 2.8 & 1.7 \\
\hline Terms of trade (goods) & -0.4 & -0.2 & -0.5 & -0.7 & 0.8 & 0.3 & -0.1 \\
\hline Consumer price index (harmonized) & 1.5 & 1.9 & 2.5 & 2.3 & 1.8 & 3.1 & 1.9 \\
\hline Labor productivity $3 /$ & 0.9 & 2.1 & 0.7 & 1.6 & 1.1 & 1.0 & 1.4 \\
\hline \multicolumn{8}{|l|}{ Interest rates (percent) } \\
\hline Money market rate (3 month) & 2.3 & 2.1 & 2.2 & 3.1 & 4.3 & $\cdots$ & $\ldots$ \\
\hline Government bond yield & 4.2 & 4.2 & 3.4 & 3.8 & 4.3 & $\cdots$ & $\ldots$ \\
\hline \multicolumn{8}{|l|}{ Saving and investment (in percent of GDP) } \\
\hline Private saving & 23.3 & 23.7 & 23.8 & 24.9 & 25.6 & 25.3 & 25.3 \\
\hline Private investment & 17.1 & 18.1 & 18.6 & 19.1 & 19.3 & 19.1 & 19.0 \\
\hline Private saving surplus & 6.1 & 5.6 & 5.2 & 5.8 & 6.3 & 6.1 & 6.3 \\
\hline Government saving surplus & -1.7 & -1.7 & -1.8 & -1.7 & -2.1 & -2.2 & -2.5 \\
\hline National saving surplus & 4.4 & 3.9 & 3.4 & 4.1 & 4.2 & 3.9 & 3.7 \\
\hline \multicolumn{8}{|c|}{ Public finances, general government (in percent of GDP) 4/ } \\
\hline Revenue & 51.1 & 49.2 & 49.4 & 48.7 & 48.5 & 48.3 & 48.1 \\
\hline Expenditure & 51.1 & 49.2 & 51.6 & 48.4 & 48.7 & 48.7 & 48.9 \\
\hline Of which: interest on public debt & 5.3 & 4.7 & 4.2 & 4.0 & 3.8 & 3.7 & 3.6 \\
\hline Fiscal balance & 0.0 & 0.0 & -2.3 & 0.4 & -0.1 & -0.3 & -0.7 \\
\hline Primary balance & 5.3 & 4.7 & 1.9 & 4.3 & 3.7 & 3.4 & 2.9 \\
\hline Structural balance $5 /$ & -1.0 & -0.6 & 0.4 & -0.1 & -0.1 & 0.0 & 0.0 \\
\hline Gross public debt & 98.7 & 94.4 & 92.2 & 88.1 & 85.1 & 82.0 & 80.3 \\
\hline \multicolumn{8}{|l|}{ Balance of payments } \\
\hline Current account balance (in billions of euros) & 11.4 & 10.2 & 7.9 & 8.4 & 10.7 & 10.0 & 10.0 \\
\hline (In percent of GDP) & 4.1 & 3.5 & 2.6 & 2.7 & 3.2 & 2.9 & 2.8 \\
\hline Trade balance (in billions of euros) & 9.7 & 7.8 & 4.7 & 2.6 & 3.8 & 4.3 & 5.0 \\
\hline (In percent of GDP) & 3.5 & 2.7 & 1.6 & 0.8 & 1.2 & 1.2 & 1.4 \\
\hline \multicolumn{8}{|l|}{ Exchange rates } \\
\hline Nominal effective rate $(2000=100)$ & 105.7 & 106.8 & 106.9 & 107.3 & 109.1 & $\ldots$ & $\ldots$ \\
\hline Real effective rate $(2000=100) 6 /$ & 110.3 & 111.9 & 113.3 & 115.0 & 117.6 & $\ldots$ & $\ldots$ \\
\hline
\end{tabular}

Sources: Data provided by the authorities; and IMF staff estimates and projections.

$1 /$ Contribution to growth.

2/ Percent of the labor force.

3/ Based on national accounts data, for economy-wide.

4/ Includes the effect of the restructuring of the national railway company in 2005 as presented by Eurostat. 5/ Excludes effect of one-off measures, including the restructuring of the national railway company in 2005.

6 / Based on relative unit labor costs in manufacturing. 
Table 2. Belgium: Fiscal Scenarios, 2004-13

(In percent of GDP, unadjusted for working days; unless otherwise indicated)

\begin{tabular}{|c|c|c|c|c|c|c|c|c|c|c|}
\hline & \multirow[b]{2}{*}{2004} & \multirow[b]{2}{*}{2005} & \multirow[b]{2}{*}{2006} & \multirow{2}{*}{$\begin{array}{r}\text { Est. } \\
2007\end{array}$} & \multicolumn{6}{|c|}{ Projection } \\
\hline & & & & & 2008 & 2009 & 2010 & 2011 & 2012 & 2013 \\
\hline \multicolumn{11}{|l|}{ Current policies (A) } \\
\hline Revenue & 49.2 & 49.4 & 48.7 & 48.5 & 48.3 & 48.1 & 48.1 & 48.0 & 48.0 & 47.9 \\
\hline Expenditure & 49.2 & 51.6 & 48.4 & 48.7 & 48.7 & 48.9 & 48.3 & 48.1 & 48.0 & 47.8 \\
\hline Primary expenditure & 44.5 & 47.5 & 44.4 & 44.8 & 45.0 & 45.3 & 44.9 & 44.8 & 44.7 & 44.7 \\
\hline Interest payments & 4.7 & 4.2 & 4.0 & 3.8 & 3.7 & 3.6 & 3.5 & 3.3 & 3.2 & 3.1 \\
\hline Balance 1/ & 0.0 & -2.3 & 0.4 & -0.1 & -0.3 & -0.7 & -0.2 & -0.1 & 0.0 & 0.1 \\
\hline Structural balance 2/ & -0.6 & 0.4 & -0.1 & -0.1 & 0.0 & 0.0 & 0.1 & 0.1 & 0.2 & 0.2 \\
\hline Change in structural balance & 0.5 & 0.9 & -0.5 & 0.0 & 0.0 & 0.0 & 0.1 & 0.1 & 0.1 & 0.1 \\
\hline Primary balance & 4.7 & 1.9 & 4.3 & 3.7 & 3.4 & 2.9 & 3.2 & 3.3 & 3.3 & 3.2 \\
\hline Structural primary balance 2/ & 4.2 & 4.5 & 3.8 & 3.7 & 3.6 & 3.6 & 3.5 & 3.5 & 3.4 & 3.3 \\
\hline Debt $1 /$ & 94.4 & 92.2 & 88.1 & 85.1 & 82.0 & 80.3 & 77.1 & 74.3 & 71.6 & 68.9 \\
\hline \multicolumn{11}{|l|}{ Memorandum items (in percent): } \\
\hline Real primary expenditure growth 2/ & -0.2 & 8.9 & -3.7 & 3.7 & 1.7 & 1.8 & 1.9 & 1.9 & 1.9 & 1.9 \\
\hline Output gap & 0.0 & -0.2 & 0.2 & 0.5 & -0.4 & -1.2 & -0.3 & -0.1 & 0.0 & 0.0 \\
\hline GDP growth & 2.8 & 2.0 & 2.9 & 2.7 & 1.4 & 1.2 & 2.8 & 2.2 & 2.0 & 2.0 \\
\hline \multicolumn{11}{|l|}{ Staff-recommended scenario (B) } \\
\hline Revenue & 49.2 & 49.4 & 48.7 & 48.5 & 48.3 & 48.1 & 48.1 & 48.0 & 48.0 & 47.9 \\
\hline Expenditure & 49.2 & 51.6 & 48.4 & 48.7 & 48.2 & 48.0 & 47.2 & 46.7 & 46.4 & 46.0 \\
\hline Primary expenditure & 44.5 & 47.5 & 44.4 & 44.8 & 44.5 & 44.4 & 43.8 & 43.5 & 43.3 & 43.1 \\
\hline Interest payments & 4.7 & 4.2 & 4.0 & 3.8 & 3.7 & 3.6 & 3.4 & 3.2 & 3.1 & 2.9 \\
\hline Balance 1/ & 0.0 & -2.3 & 0.4 & -0.1 & 0.2 & 0.2 & 0.9 & 1.3 & 1.6 & 1.9 \\
\hline Structural balance 2/ & -0.6 & 0.4 & -0.1 & -0.1 & 0.4 & 0.9 & 1.2 & 1.5 & 1.8 & 2.0 \\
\hline Change in structural balance & 0.5 & 0.9 & -0.5 & 0.0 & 0.5 & 0.5 & 0.3 & 0.3 & 0.3 & 0.3 \\
\hline Primary balance & 4.7 & 1.9 & 4.3 & 3.7 & 3.8 & 3.8 & 4.3 & 4.5 & 4.7 & 4.8 \\
\hline Structural primary balance 2/ & 4.2 & 4.5 & 3.8 & 3.7 & 4.1 & 4.4 & 4.6 & 4.7 & 4.8 & 4.9 \\
\hline Debt $1 /$ & 94.4 & 92.2 & 88.1 & 85.1 & 81.5 & 79.0 & 74.6 & 70.5 & 66.4 & 62.1 \\
\hline \multicolumn{11}{|l|}{ Memorandum items (in percent): } \\
\hline Real primary expenditure growth 2/ & -0.2 & 8.9 & -3.7 & 3.7 & 0.7 & 0.9 & 1.2 & 1.5 & 1.5 & 1.6 \\
\hline Output gap & 0.0 & -0.2 & 0.2 & 0.5 & -0.4 & -1.3 & -0.4 & -0.2 & -0.1 & -0.1 \\
\hline GDP growth & 2.8 & 2.0 & 2.9 & 2.7 & 1.4 & 1.1 & 2.7 & 2.2 & 2.0 & 2.0 \\
\hline
\end{tabular}

Sources: Data provided by the authorities; and IMF staff projections.

$1 /$ Includes the effect of the restructuring of the national railway company in 2005 as presented by Eurostat. According to the authorities, the government balance should be 0.1 percent of GDP in 2005 and the public debt 91.5 percent of GDP.

2/ Excludes one-off measures including the restructuring of the national railway company in 2005. 


\section{INTERNATIONAL MONETARY FUND}

EXTERNAL

Public Information Notice

RELATIONS

DEPARTMENT

Public Information Notice (PIN) No. 08/40

FOR IMMEDIATE RELEASE

March 28, 2008

International Monetary Fund

$70019^{\text {th }}$ Street, NW

Washington, D. C. 20431 USA

\section{IMF Executive Board Concludes 2007 Article IV Consultation with Belgium}

On March 21, 2008, the Executive Board of the International Monetary Fund (IMF) concluded the Article IV consultation with Belgium.

\section{Background}

With a supportive external environment and buoyant domestic demand, GDP is estimated to have grown by 2.7 percent in 2007 and unemployment declined to its lowest level since 2002. Rapid job creation contributed to rising households' net disposable income and private consumption. Meanwhile, business investment firmed up, boosted by strong net revenue growth in the first half of 2007. However, headwinds from a worsening international environment, combined with domestic political tensions, contributed to a slowdown of activity toward the end of the year.

Looking ahead, the spike in oil prices, euro appreciation, the spillovers from the global financial turmoil, and dimmer economic prospects in partner countries will exert a drag on activity. Hence, the staff projects output growth to weaken to 1.4 percent in 2008. Greater economic uncertainty and less favorable financing conditions will lower business investment and consumption will decelerate in response to more sluggish real disposable income growth and a slower pace of job creation. Moreover, concerns about the depth and persistence of the ongoing financial market turmoil and its effects on growth constitute downside risks.

\footnotetext{
${ }^{1}$ Under Article IV of the IMF's Articles of Agreement, the IMF holds bilateral discussions with members, usually every year. A staff team visits the country, collects economic and financial information, and discusses with officials the country's economic developments and policies. On return to headquarters, the staff prepares a report, which forms the basis for discussion by the Executive Board. At the conclusion of the discussion, the Managing Director, as Chairman of the Board, summarizes the views of Executive Directors, and this summary is transmitted to the country's authorities.
} 
Headline inflation has risen to 3.5 percent in January 2008 with the surge in food and energy prices. Partial wage indexation will boost wages and shield purchasing power, but it will drive up hourly labor costs in excess of what was envisaged in earlier wage agreements. These agreements contained moderate wage increases to help preserve competitiveness. The authorities have responded to the energy price spike by raising targeted income support for the energy needs of low-income households.

The ongoing financial turbulence has so far had only a limited impact on the financial system and the economy. Banks' exposure to the U.S. subprime market is small, bank capitalization is strong, and liquidity shocks have been absorbed. Nonetheless, recent volatility in equity prices as well as a widening of credit default spreads indicates continuing market concerns about asset valuations and their implications for banks' earnings and capital. Meanwhile, the crossborder dimension of the financial system has gained further importance with a partial merger between a Belgian and Dutch bank.

With political tensions following the June 2007 elections, federal policy making has been at a standstill, delaying fiscal consolidation and structural reforms. The 2007 general government outcome is estimated to show a small deficit, short of the planned surplus of 0.3 percent of GDP. The stance of fiscal policy was broadly neutral, with the structural balance remaining close to balance. The authorities agreed on resuming fiscal consolidation and balancing the 2008 general government budget. Current fiscal federalism arrangements have led to unsustainable fiscal imbalances, both between the federal and regional entities and between the regions, but lack of consensus about a new allocation of competencies between federal and regional governments has delayed their reform.

Demographic trends are projected to dampen long-term growth, as population aging curbs labor supply and sharply raises dependency ratios. Despite recent increases, employment rates remain among the lowest in the industrialized world. At the same time, skill mismatches and geographical differences in growth and income persist, amid limited labor mobility.

\section{Executive Board Assessment}

Executive Directors welcomed the upswing of recent years with robust growth continuing in 2007 that brought unemployment down to a low level. Directors noted, however, that the economy now faces headwinds, largely due to external factors. They commended the authorities for their prudent 2008 budget and the well-targeted approach to addressing the consequences of the spike in inflation. Looking forward, Directors noted the need to address population aging, and encouraged the authorities to adopt a program of medium-term fiscal consolidation and implement reforms to raise employment rates and productivity.

Directors noted that prudent domestic policies are called for to meet the challenge of the nearterm outlook. With protracted global financial turmoil and the slowdown in partner countries, GDP growth is expected to weaken in 2008 and remain subdued in 2009 . This combined with a sharp rise in inflation presents significant policy challenges. They encouraged the authorities to allow fiscal stabilizers to operate fully around a medium-term consolidation path and avoid recourse to one-off measures to achieve nominal budget objectives. Given the widespread 
practice of wage indexation and the increase in targeted support for low-income households, they felt that purchasing power is adequately protected and called for continued wage moderation to prevent a further erosion in competitiveness.

Directors noted that the financial system had been only moderately affected by the recent financial market turbulence, but cautioned that its resilience was likely to be tested further. They supported the authorities' encouragement of early and transparent disclosure and saw the need to ensure that financial institutions maintain adequate capital buffers to deal with further risks. Directors welcomed the authorities' continuing efforts to further enhance already high-quality supervision, and noted that-with ongoing cross-border consolidation modifying the financial landscape considerably-deeper coordination with host country authorities will be needed.

Recognizing that the political situation had caused delays in policymaking, Directors encouraged the new government to take decisive and medium-term oriented action. They welcomed the intention to achieve a balanced budget for the general government in 2008, underpinned by the regional authorities' efforts to aim for a larger-than-planned surplus. Nonetheless, Directors felt that the credibility of the authorities' strategy to deal with aging will depend on promptly adopting the structural expenditure restraint needed to return the fiscal consolidation path to that recommended by the High Finance Council, and on making up for recently lost ground over the medium term.

Directors welcomed the authorities' intention to revise fiscal federalism arrangements to address fiscal imbalances among different levels of government. They underscored that any new agreements should be neutral from a consolidated budget perspective, provide incentives for regions to narrow income differences, and be transparent about the intergovernmental solidarity mechanisms. Directors noted that further devolution of competencies would need to be accompanied by strengthened accountability and stronger coordination among federal and sub-federal entities of economic policies, for which existing fiscal institutions may need to be strengthened.

Directors saw labor and product market reforms as vital to raise growth, reduce unemployment, increase employment rates, and boost productivity. They recommended comprehensive reforms that would involve a further streamlining and coordinating of labor market policies across regions, an improvement in training and education, a revision of the tax-benefit system, and phasing out early retirement schemes. Directors felt that the wage bargaining framework ought to be made more conducive to achieving higher employment rates.

Public Information Notices (PINs) form part of the IMF's efforts to promote transparency of the IMF's views and analysis of economic developments and policies. With the consent of the country (or countries) concerned, PINs are issued after Executive Board discussions of Article IV consultations with member countries, of its surveillance of developments at the regional level, of post-program monitoring, and of ex post assessments of member countries with longer-term program engagements. PINs are also issued after Executive Board discussions of general policy matters, unless otherwise decided by the Executive Board in a particular case. The staff report (use the free Adobe Acrobat Reader to view this pdf file) for the 2007 Article IV Consultation with Belgium is also available. 
Belgium: Selected Economic and Social Indicators

(Annual percentage change; unless otherwise indicated)

\begin{tabular}{|c|c|c|c|c|c|c|}
\hline & 2003 & 2004 & 2005 & 2006 & $20071 /$ & $20081 /$ \\
\hline \multicolumn{7}{|l|}{ Real economy } \\
\hline Real GDP & 1.0 & 2.8 & 2.0 & 2.9 & 2.7 & 1.4 \\
\hline Domestic demand & 0.9 & 2.9 & 2.4 & 2.8 & 2.9 & 1.8 \\
\hline CPI Inflation & 1.5 & 1.9 & 2.5 & 2.3 & 1.8 & 3.1 \\
\hline Unemployment rate (in percent) & 8.2 & 8.4 & 8.4 & 8.2 & 7.5 & 7.6 \\
\hline Gross national saving (percent of GDP) & 23.2 & 23.6 & 23.8 & 24.9 & 25.2 & 24.6 \\
\hline Gross domestic investment (percent of GDP) & 19.1 & 20.1 & 21.2 & 22.2 & 21.9 & 21.7 \\
\hline \multicolumn{7}{|l|}{ Public finance (percent of GDP) 2/ } \\
\hline General government balance & 0.0 & 0.0 & -2.3 & 0.4 & -0.1 & -0.3 \\
\hline Structural balance & -1.0 & -0.6 & 0.4 & -0.1 & -0.1 & 0.0 \\
\hline Primary balance & 5.3 & 4.7 & 1.9 & 4.3 & 3.7 & 3.4 \\
\hline General government debt & 98.7 & 94.4 & 92.2 & 88.1 & 85.1 & 82.0 \\
\hline \multicolumn{7}{|l|}{ Interest rates (percent) } \\
\hline Money market rate (3 months) & 2.3 & 2.1 & 2.2 & 3.1 & 4.2 & $\ldots$ \\
\hline Government bond yield & 4.2 & 4.1 & 3.4 & 3.9 & 4.3 & $\ldots$ \\
\hline \multicolumn{7}{|l|}{ Balance of payments $3 /$} \\
\hline Exports of goods (percent of GDP) & 66.0 & 68.3 & 70.0 & 70.6 & 74.6 & 76.5 \\
\hline Volume growth & 2.9 & 6.3 & 4.1 & 2.6 & 5.6 & 5.7 \\
\hline Imports of goods (percent of GDP) & -62.5 & -65.6 & -68.4 & -69.8 & -73.5 & -75.2 \\
\hline Volume growth & 2.8 & 6.5 & 4.9 & 2.5 & 6.0 & 5.9 \\
\hline Trade balance (percent of GDP), of which: & 3.5 & 2.7 & 1.6 & 0.8 & 1.2 & 1.2 \\
\hline Oil (US\$ billion) & -6.8 & -10.0 & -16.1 & -16.4 & -18.1 & -20.1 \\
\hline Current account (percent of GDP) & 4.1 & 3.5 & 2.6 & 2.7 & 3.2 & 2.9 \\
\hline FDI (percent of GDP) & 10.8 & 12.1 & 9.2 & 16.1 & . & $\ldots$ \\
\hline Official reserves (US\$ billion) 4/ & 11.0 & 10.4 & 8.2 & 8.8 & 8.7 & $\ldots$ \\
\hline \multicolumn{7}{|l|}{ Fund position (February 12, 2008) } \\
\hline Holdings of currency (percent of quota) & $\ldots$ & $\ldots$ & $\ldots$ & $\ldots$ & $\ldots$ & 91.9 \\
\hline Holdings of SDRs (percent of allocation) & $\ldots$ & $\ldots$ & $\ldots$ & $\ldots$ & $\ldots$ & 74.3 \\
\hline Quota (SDR millions) & $\ldots$ & $\ldots$ & $\ldots$ & $\ldots$ & $\ldots$ & 4605.2 \\
\hline \multicolumn{7}{|l|}{ Exchange rate } \\
\hline Nominal effective rate $(2000=100$, ULC & & & & & & \\
\hline based) 4/ & 105.7 & 106.8 & 106.2 & 108.2 & 108.1 & \\
\hline Real effective rate $(2000=100$, ULC based $) 4 /$ & 110.3 & 111.9 & 113.2 & 115.4 & 116.2 & $\ldots$ \\
\hline
\end{tabular}

Social Indicators (reference year):

Per capita GDP (2006): $\$ 37,301$; Income distribution (ratio of income received by top and bottom quintiles, 2005): 4.1; Life expectancy at birth (2005): male: 76.7, female: 82.4; Gender pay gap (as percent of male pay, 2005): 7; Passenger car ownership (2000): 467 per thousand inhabitants;

Greenhouse gas emissions (2003): kg CO2 per capita: 11.2; Population density (2006):

343.6 inhabitants per sq. km.; At-risk-of-poverty rate (2005): 15 percent.

$1 /$ Staff estimates and projections.

2/ Staff projections for 2008, assuming no policy adjustment. According to Eurostat, the debt transfer of the national railway company to the Railway Infrastructure Fund should be accounted as expenditure in 2005.

3/ Staff projections for 2007-08.

4/ Data for 2007 refer to end-December 2007. 